Prepared in cooperation with the Federal Emergency Management Agency

\title{
Flash Floods of August 10, 2009, in the Villages of Gowanda and Silver Creek, New York
}

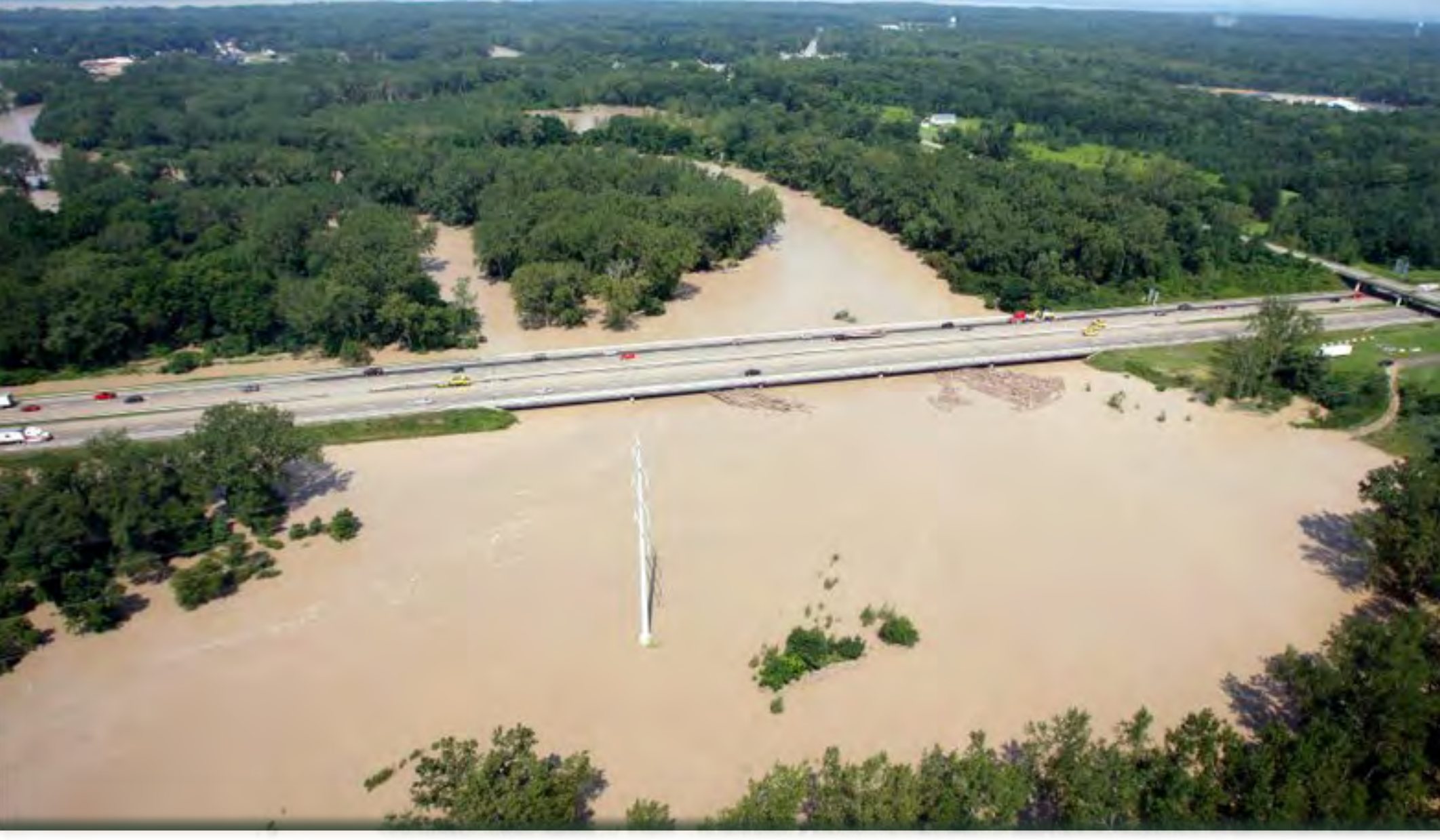

Scientific Investigations Report 2010-5259 
Cover. Cattaraugus Creek at New York State Thruway, August 10, 2009 (photo courtesy of The Buffalo News, Buffalo, N.Y.) 


\section{Flash Floods of August 10, 2009, in the Villages of Gowanda and Silver Creek, New York}

By Carolyn 0. Szabo, William F. Coon, and Thomas A. Niziol

Prepared in cooperation with the Federal Emergency Management Agency

Scientific Investigations Report 2010-5259 


\section{U.S. Department of the Interior \\ KEN SALAZAR, Secretary \\ U.S. Geological Survey \\ Marcia K. McNutt, Director}

U.S. Geological Survey, Reston, Virginia: 2010

This and other USGS information products are available at http://store.usgs.gov/
U.S. Geological Survey
Box 25286 , Denver Federal Center
Denver, CO 80225
To learn about the USGS and its information products visit http://www.usgs.gov/
1-888-ASK-USGS

Any use of trade, product, or firm names is for descriptive purposes only and does not imply endorsement by the U.S. Government.

Although this report is in the public domain, permission must be secured from the individual copyright owners to reproduce any copyrighted materials contained within this report.

Suggested citation:

Szabo, C.0., Coon, W.F., and Niziol, T.A., 2010, Flash floods of August 10, 2009, in the Villages of Gowanda and Silver Creek, New York: U.S. Geological Survey Scientific Investigations Report 2010-5259, 23 p. 


\section{Contents}

Abstract

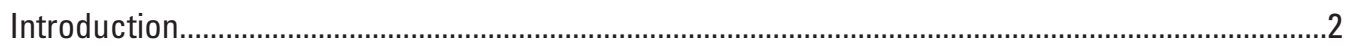

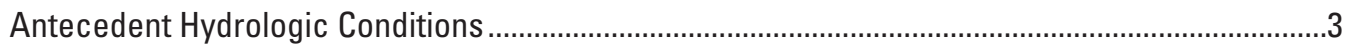

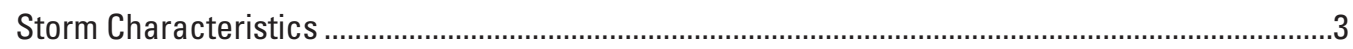

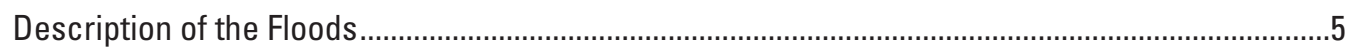

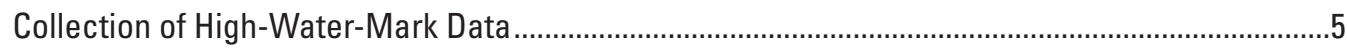

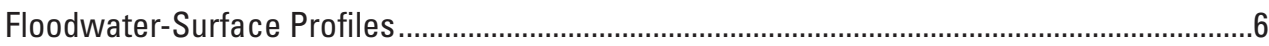

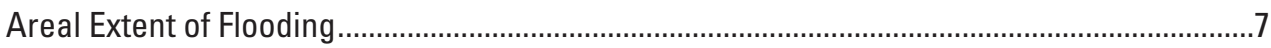

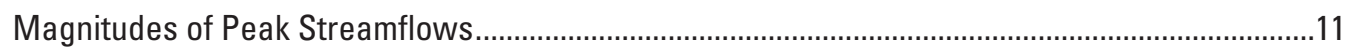

Annual Exceedance Probabilities of Peak Streamflows...............................................................11

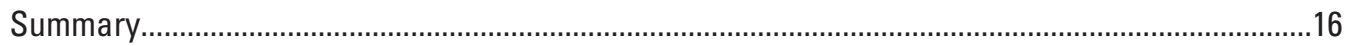

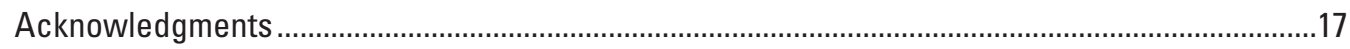

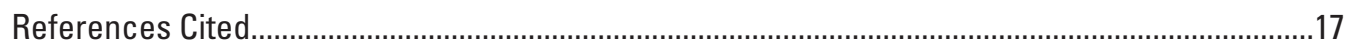

Appendix 1. High-water marks in the Villages of Gowanda and Silver Creek, N.Y.,

for the flash floods of August 10, 2009............................................................................20

\section{Figures}

1. Map showing locations of study sites and selected U.S. Geological Survey streamgages and associated drainage basins in western New York...........2

2. Map showing storm-total radar-derived precipitation in western New York from 9:09 p.m. on August 9, 2009, through 12:09 a.m. Eastern Daylight Time on August 10, 2009..........................................................................

3. Photographs of damage from the floods of August 10, 2009 ...................................

4. Graph showing streamflow and gage-height for Cattaraugus Creek at Gowanda, New York, U.S. Geological Survey station 04213500, August 9-12, 2009......

5. Examples of representative high-water marks from the floods of August 10, 2009: $(A)$ debris line, $(B)$ wash line, $(C$ and $D)$ mud lines, and $(E)$ grass on tree

6. Graph showing water-surface elevations for the August 10, 2009, flood and the FEMA 0.2-percent annual exceedance probability flood for Grannis Brook at Gowanda, N.Y.

7. Graph showing water-surface elevations for the August 10, 2009, flood and the FEMA 0.2-percent annual exceedance probability flood for Thatcher Brook at Gowanda, N.Y.

8. Graph showing water-surface elevations for the August 10, 2009, flood and the FEMA 0.2-percent annual exceedance probability flood for Walnut Creek at Silver Creek, N.Y.

9. Graph showing ater-surface elevations for the August 10, 2009, flood and the FEMA 0.2-percent annual exceedance probability flood for Silver Creek at Silver Creek, N.Y

10. Map showing areal extent and water-surface elevations of flooding in Gowanda, N.Y., August 10, 2009

11. Map showing areal extent and water-surface elevations of flooding in Silver Creek, N.Y., August 10, 2009. 


\section{Tables}

1. Historic peak flows, and peak flows and associated annual exceedance probabilities for the floods of August 10, 2009, at selected U.S. Geological Survey streamgages in western New York.

2. Peak flows computed for the floods of August 10, 2009, at sites in Gowanda and Silver Creek, New York

3. Peak flows for indicated annual exceedance probabilities for selected streams in Gowanda and Silver Creek, New York

\section{Conversion Factors, Datums, and Abbreviations}

\begin{tabular}{|c|c|c|}
\hline Multiply & By & To obtain \\
\hline \multicolumn{3}{|c|}{ Length } \\
\hline inch (in.) & 2.54 & centimeter $(\mathrm{cm})$ \\
\hline inch (in.) & 25.4 & millimeter $(\mathrm{mm})$ \\
\hline foot $(\mathrm{ft})$ & 0.3048 & meter $(\mathrm{m})$ \\
\hline mile (mi) & 1.609 & kilometer $(\mathrm{km})$ \\
\hline \multicolumn{3}{|c|}{ Area } \\
\hline square mile $\left(\mathrm{mi}^{2}\right)$ & 259.0 & hectare (ha) \\
\hline square mile $\left(\mathrm{mi}^{2}\right)$ & 2.590 & square kilometer $\left(\mathrm{km}^{2}\right)$ \\
\hline \multicolumn{3}{|c|}{ Volume } \\
\hline cubic foot $\left(\mathrm{ft}^{3}\right)$ & 0.02832 & cubic meter $\left(\mathrm{m}^{3}\right)$ \\
\hline \multicolumn{3}{|c|}{ Flow rate } \\
\hline foot per second (ft/s) & 0.3048 & meter per second $(\mathrm{m} / \mathrm{s})$ \\
\hline cubic foot per second $\left(\mathrm{ft}^{3} / \mathrm{s}\right)$ & 0.02832 & cubic meter per second $\left(\mathrm{m}^{3} / \mathrm{s}\right)$ \\
\hline $\begin{array}{l}\text { cubic foot per second per square mile } \\
{\left[\left(\mathrm{ft}^{3} / \mathrm{s}\right) / \mathrm{mi}^{2}\right]}\end{array}$ & 0.01093 & $\begin{array}{l}\text { cubic meter per second per square } \\
\text { kilometer }\left[\left(\mathrm{m}^{3} / \mathrm{s}\right) / \mathrm{km}^{2}\right]\end{array}$ \\
\hline
\end{tabular}

Vertical coordinate information is referenced to the National Geodetic Vertical Datum of 1929 (NGVD29) or the North American Vertical Datum of 1988 (NAVD88), as noted.

Horizontal coordinate information is referenced to the North American Datum of 1983 (NAD83).

Elevation, as used in this report, refers to distance above the vertical datum.

\section{Abbreviations}

$\begin{array}{ll}\text { EDT } & \text { Eastern Daylight Time } \\ \text { EST } & \text { Eastern Standard Time } \\ \text { FEMA } & \text { Federal Emergency Management Agency } \\ \text { HEC-RAS } & \text { Hydrologic Engineering Center River Analysis System } \\ \text { LiDAR } & \text { Light Detection And Ranging } \\ \text { NAD83 } & \text { North American Datum of 1983 } \\ \text { NAVD88 } & \text { North American Vertical Datum of 1988 } \\ \text { NGVD29 } & \text { National Geodetic Vertical Datum of 1929 } \\ \text { NOAA } & \text { National Oceanic and Atmospheric Administration } \\ \text { NWS } & \text { National Weather Service } \\ \text { SPCS } & \text { State Plane Coordinate System } \\ \text { USDA } & \text { U.S. Department of Agriculture } \\ \text { USGS } & \text { U.S. Geological Survey }\end{array}$




\title{
Flash Floods of August 10, 2009, in the Villages of Gowanda and Silver Creek, New York
}

\author{
By Carolyn 0. Szabo ${ }^{1}$, William F. Coon ${ }^{1}$, and Thomas A. Niziol ${ }^{2}$
}

\section{Abstract}

Late during the night of August 9, 2009, two storm systems intersected over western New York and produced torrential rain that caused severe flash flooding during the early morning hours of August 10 in parts of Cattaraugus, Chautauqua, and Erie Counties. Nearly 6 inches of rain fell in 1.5 hours as recorded by a National Weather Service weather observer in Perrysburg, which lies between Gowanda and Silver Creek - the communities that suffered the most damage. This storm intensity had an annual exceedance probability of less than 0.2 percent (recurrence interval greater than 500 years). Although flooding along Cattaraugus Creek occurred elsewhere, Cattaraugus Creek was responsible for very little flooding in Gowanda. Rather the small tributaries, Thatcher Brook and Grannis Brook, caused the flooding in Gowanda, as did Silver Creek and Walnut Creek in the Village of Silver Creek.

Damages from the flooding were widespread. Numerous road culverts were washed out, and more than one-quarter of the roads in Cattaraugus County were damaged. Many people were evacuated or rescued in Gowanda and Silver Creek, and two deaths occurred during the flood in Gowanda. The water supplies of both communities were compromised by damages to village reservoirs and water-transmission infrastructures. Water and mud damage to residential and commercial properties was extensive. The tri-county area was declared a Federal disaster area and more than $\$ 45$ million in Federal disaster assistance was distributed to more than 1,500 individuals and an estimated 1,100 public projects. The combined total estimate of damages from the flash floods was greater than $\$ 90$ million.

Over 240 high-water marks were surveyed by the U.S. Geological Survey; a subset of these marks was used to create flood-water-surface profiles for four streams and to delineate the areal extent of flooding in Gowanda and Silver Creek.

\footnotetext{
U.S. Geological Survey, New York Water Science Center, Ithaca, N.Y.

${ }^{2}$ National Oceanic and Atmospheric Administration, National Weather Service, Buffalo, N.Y.
}

Flood elevations exceeded previously defined 0.2 -percent annual exceedance probability (500-year recurrence interval) elevations by 2 to 4 feet in Gowanda and as much as 6 to 8 feet in Silver Creek. Most of the high-water marks were used in indirect hydraulic computations to estimate peak flows for four streams. The peak flows in Grannis Brook and Thatcher Brook were computed, using the slope-area method, to be 1,400 and 7,600 cubic feet per second, respectively, and peak flow in Silver Creek was computed, using the widthcontraction method, to be 19,500 cubic feet per second. The annual exceedance probabilities for flows in these and other basins with small drainage areas that fell almost entirely within the area of heaviest precipitation were less than 0.2 percent (or recurrence intervals greater than 500 years). The peak flow in Cattaraugus Creek at Gowanda was computed, using the slope-area method, to be 33,200 cubic feet per second with an annual exceedance probability of 2.2 percent (recurrence interval of 45 years).

\section{Introduction}

Severe thunderstorms during the night of August 9, 2009, caused extensive flooding during the early hours of August 10 across parts of Cattaraugus, Chautauqua, and Erie Counties in western New York (fig. 1). Although many road culverts were washed out and more than one-quarter of the roads in Cattaraugus County were damaged (National Oceanic and Atmospheric Administration, 2010a), the major damages and costs occurred in the residential and commercial sections of villages, such as Gowanda and Silver Creek. The flooding was caused by runoff from torrential rainfall that exceeded the capacity of small streams that flowed through these communities. Many people were evacuated or rescued in both communities, including patients in the Tri-County Memorial Hospital in Gowanda and residents of a creek-side trailer park in Silver Creek, which was destroyed. The water supplies of both communities were compromised by damages to village reservoirs and water-transmission infrastructures. Water depth in the flooded areas was about 1 to $3 \mathrm{ft}$, enough to fill basements and inundate the first floor of hundreds of homes and businesses. Damages resulted not only from water but also from mud that was carried by the sediment-laden floodwaters. 


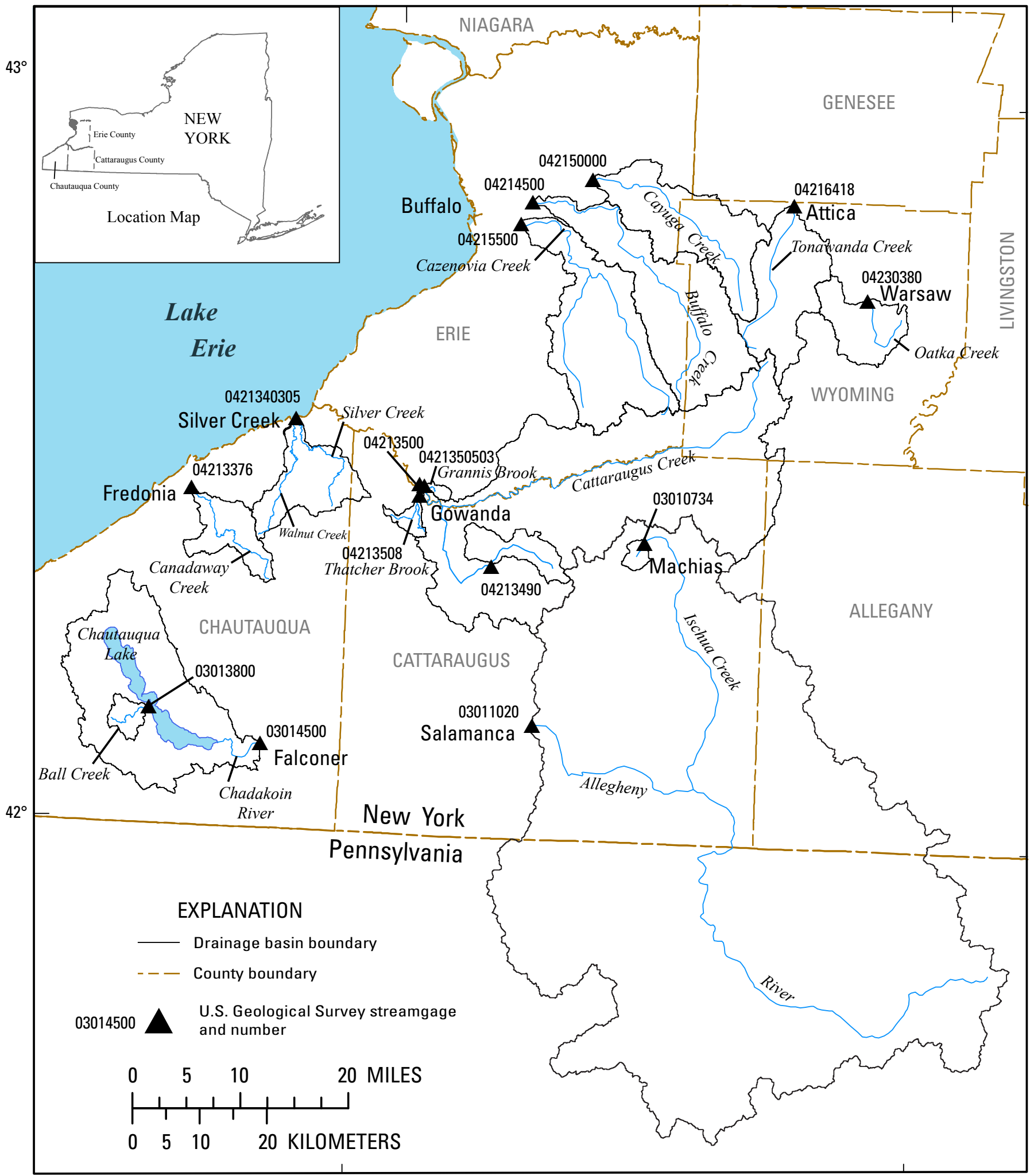

Base from USGS digital data, Zone 18, Universal Transverse Mercator

Figure 1. Locations of study sites and selected U.S. Geological Survey streamgages and associated drainage basins in western New York. (Streamgage names are listed in table 1.) 
Two deaths occurred during the flood in Gowanda. One resident suffered a heart attack while emergency responders were delayed by flooded streets. A second resident drowned when he was swept into the rising floodwaters of Thatcher Brook (Fairbanks and others, 2009). The tri-county area was declared a Federal disaster area on September 1, 2009 (Federal Emergency Management Agency, 2009a). More than \$45 million in Federal disaster assistance was distributed to fund the recovery efforts of more than 1,500 individuals and an estimated 1,100 public projects (Federal Emergency Management Agency, 2009b). The total cost of damages estimated by emergency managers in the affected counties and municipalities exceeded $\$ 90$ million (National Oceanic and Atmospheric Administration, 2010a).

In 2009 the U.S. Geological Survey (USGS), in cooperation with the Federal Emergency Management Agency (FEMA), conducted a study to document the meteorological and hydrologic conditions that resulted in the damaging flash floods on August 10, 2009, in western New York. This report presents high-water elevations and maps of the areal extent of flooding that occurred in Gowanda and Silver Creek. Peak flows, estimated by indirect measurement methods for Grannis Brook, Thatcher Brook, and Cattaraugus Creek at or near the Village of Gowanda, and for Silver Creek (downstream from the confluence with Walnut Creek) at the Village of Silver Creek, also are presented. The magnitudes and annual exceedance probabilities (recurrence intervals) of these peak flows are compared with similar data obtained from nearby USGS continuous-record and peak-flow-only streamgages, as well as to data contained in the most recent flood-insurance studies for these communities.

\section{Antecedent Hydrologic Conditions}

Rainfall was scattered and varied in intensity during the first 3 days of August 2009. Rain fell across western New York on August 4 and ranged from 0.16 in. in Jamestown, $30 \mathrm{mi}$ southwest of the study area, to $2.69 \mathrm{in}$. in Colden, northeast of the study area; over an inch of rain was recorded by a National Weather Service (NWS) cooperative weather observer in Perrysburg, which is about $3.5 \mathrm{mi}$ west of Gowanda (National Oceanic and Atmospheric Administration, 2010b; fig. 2). No substantial precipitation fell during the next 3 days, but rain fell on August 8, and over 1 inch of rain fell across the area during the afternoon on August 9, prior to the flood-causing storm. The weather observer in Perrysburg recorded 1.29 in. of rain (National Oceanic and Atmospheric Administration, 2010b) on August 9 between 7:00 a.m. and 10:30 p.m. Eastern Daylight Time (EDT), at which time the observer emptied the rain gauge. Saturated soil conditions existed prior to the intense storm that caused the flooding. Flows in streams that were monitored by the USGS in western New York were generally above average flow levels for August, and at 10:00 p.m. EDT on August 9, just before the major storm event, flows were receding from runoff that had occurred earlier in the day.

\section{Storm Characteristics}

A detailed analysis of the storm that caused the flooding on August 10, 2009, was performed by the National Weather Service office in Buffalo (National Weather Service, 2009).

At 8:00 p.m. EDT on August 9, a line of severe thunderstorms located over Lake Ontario was moving south toward western New York (including the city of Buffalo). As the line of storms moved through Buffalo, damaging winds, frequent lightning, and heavy rainfall occurred. Although flows increased in streams, no flooding was reported because the storm was moving rapidly southward. Around 9:30 p.m. EDT, a second line of severe storms developed over Lake Erie and moved eastward over Cattaraugus and Chautauqua Counties. In addition to frequent lightning, this line of storms also produced very heavy rainfall. By 10:00 p.m. EDT the first line of storms intersected the second line and evolved from a wind-damaging weather system into a flash-flood system. The combined storms stalled for a little more than an hour roughly along the southern boundary of Erie County (over an area that included Silver Creek and Gowanda) before weakening and continuing southward to the Pennsylvania border. During the period from 10:30 p.m. on August 9, through midnight EDT on August 10, the weather observer in Perrysburg reported 5.98 in. of rainfall. Radar-derived estimates of rainfall that occurred over the 3 -hr period from 9:09 p.m. on August 9 through 12:09 a.m. EDT on August 10, 2009, (fig. 2) showed that rainfall exceeded 4 in. along a line just south of the Erie-Cattaraugus County line. On the basis of the weather observer's "ground-truth" report, the radar-derived precipitation likely underestimated the actual precipitation quantities. The combination of torrential rains and the high-relief topography of the area resulted in extensive flash flooding.

In the areas of the two communities that are the focus of this report, radar-derived estimates of precipitation give daily (not just storm) totals of 7.06 in. for Gowanda and 6.28 in. for Silver Creek (Northeast Regional Climate Center, written instructions for retrieval of site-specific radar-derived precipitation, 2008). The maximum daily total precipitation that was reported by a NWS cooperative weather observer, again the observer from Perrysburg, was 7.27 in. The Northeast Regional Climate Center assigned a recurrence interval for this daily total of 200 to 500 years. The 120-minutes duration, 500-year return-period precipitation quantity for this area is $4.18 \mathrm{in}$.; therefore, a rainfall of $5.98 \mathrm{in}$. in $90 \mathrm{~min}$ would have a recurrence interval far greater than 500 years or a percent chance of occurring during a given year of less than 0.2 percent (K. Eggleston, Northeast Regional Climate Center, written commun., 2009). 


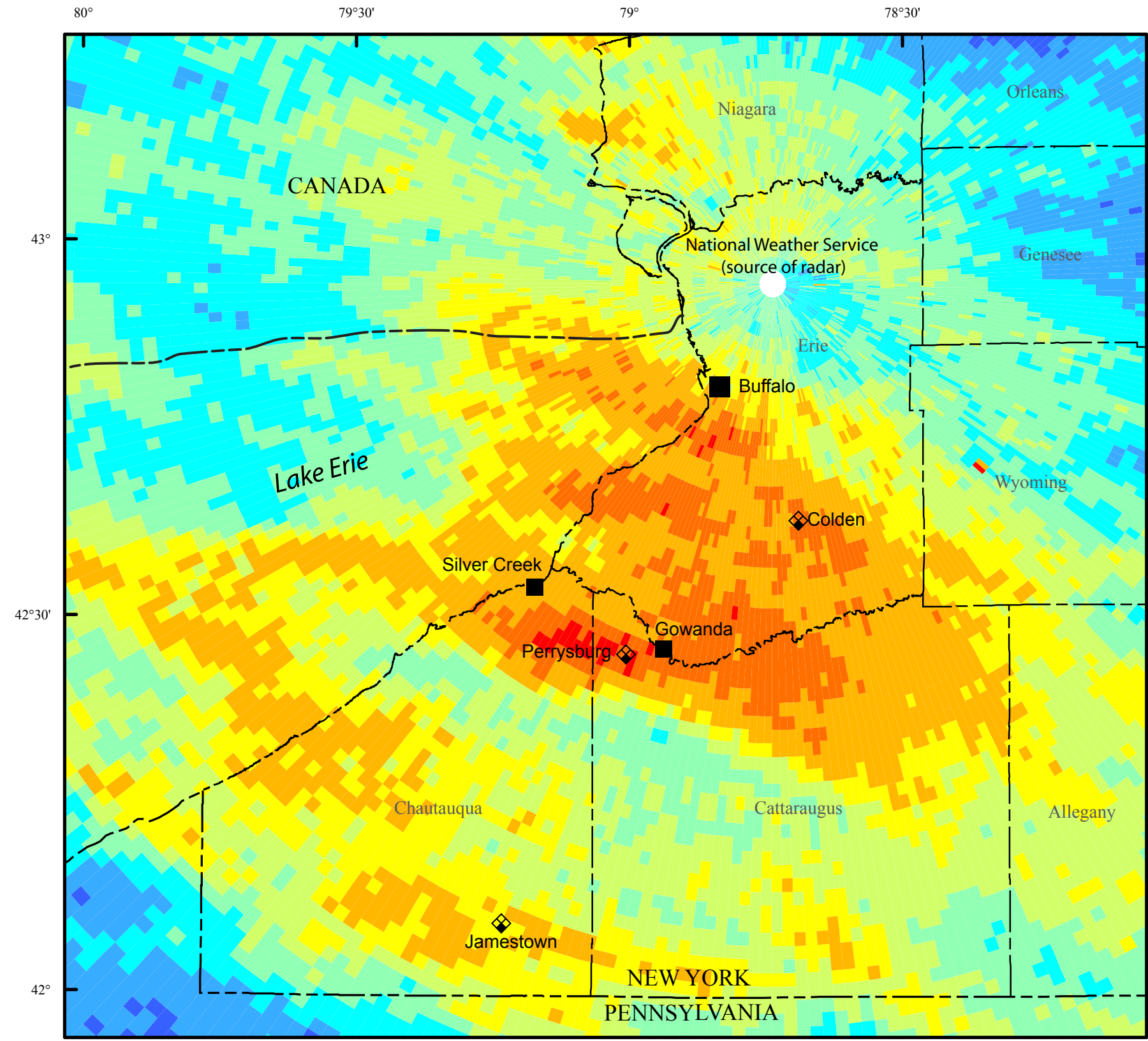

Base from U.S. Geological Survey, Seamless Data Distribution System, accessed in 2010 at http://seamless.usgs.gov

State Plane Coordinate System projection, NAD83, SPCS Zone 3103

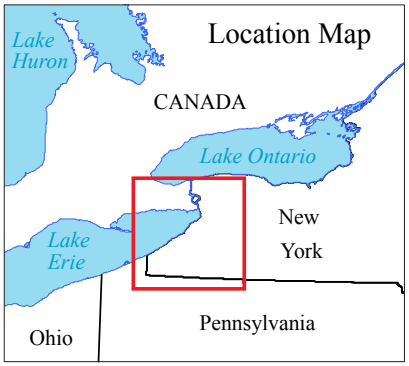

\section{EXPLANATION}

--- County boundary

Precipitation station

- Municipality

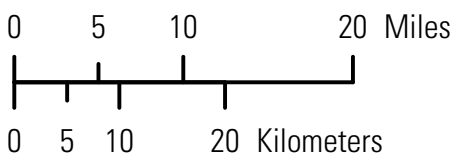

Storm-total radar derived precipitation

Inches

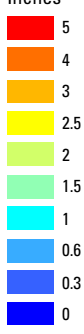

Figure 2. Storm-total radar-derived precipitation in western New York from 9:09 p.m. on August 9, 2009, through 12:09 a.m. Eastern Daylight Time on August 10, 2009. (From the National Weather Service at http://www.wbuf.noaa.gov/svrwx/web_090810_Flashflood/ indexflood.html.) 


\section{Description of the Floods}

Flooding occurred in a relatively small area of western New York, primarily limited to Cattaraugus, Chautauqua, and Erie Counties. These counties were declared disaster areas by both the State and Federal governments. Flooding was primarily due to the under-capacity of small channels to convey the runoff that was generated by the intense precipitation; therefore, the most serious flooding and damages occurred in small stream basins. Outside of developed areas, the major flood damages resulted from the overtopping of roadways and, in many cases, the erosion of road surfaces and complete removal of culverts (fig. 3). In residential and commercial areas, such as Gowanda and Silver Creek, extensive flooding and damage from water and mud occurred (fig. 3). In both of these communities, flooding occurred outside previously defined flood-prone areas and caught many residents by surprise. In addition, the rate at which floodwaters rose was unusually fast and hampered rescue efforts by local emergency responders. Walnut Creek, which joins Silver Creek within the Village of Silver Creek, reportedly rose 3 to $4 \mathrm{ft}$ in $30 \mathrm{~min}$ (T. Roche, Silver Creek Police Chief, oral commun., 2009).

In addition to the tremendous amount of runoff that was conveyed in small channels, the flooding in Gowanda was affected by the topographic characteristics of the area. Thatcher Brook and Grannis Brook approach Gowanda through high-relief areas where steep valley sides generally confine high flows. As these streams enter the village and the Cattaraugus Creek floodplain, the gradient decreases substantially, and the confining valley walls disappear. Sheetflow flooding across the residential and commercial areas of the village occurs whenever water levels exceed the tops of streambanks. Flooding on August 10, 2009, on the north side of Gowanda was exacerbated by a debris-clogged culvert on Grannis Brook. Residents of Gowanda were evacuated to a nearby school. Patients at the Tri-County Memorial Hospital in Gowanda were relocated, campers at Zoar Valley, upstream from Gowanda along Cattaraugus Creek, were rescued by helicopter, and a trailer park in Silver Creek was destroyed (Fairbanks and others, 2009; Thompson, 2009). Reservoirs that supplied water to both communities were overtopped during the floods, and the receding waters left mud, trees, and other debris behind. The water quality of these reservoirs was compromised, and the repairs to the reservoirs and watersupply infrastructures were estimated to take many months to return the reservoirs to their pre-flood functionality (Flynn, 2009).

Cattaraugus Creek at Gowanda (station 04213500) rose $5 \mathrm{ft}$ in $1 \mathrm{hr}$ between 11:35 p.m. and 12:35 a.m. EDT (10:35 to 11:35 p.m. Eastern Standard Time (EST) on August 9) and had an initial peak of $12.88 \mathrm{ft}$ at 1:35 a.m. EDT (12:35 a.m. EST) on August 10 (fig. 4). The creek receded slightly, then rose to its maximum recorded gage height of $13.47 \mathrm{ft}$ at 7:35 a.m. EDT (6:35 a.m. EST) on August 10.
The tributaries entering Cattaraugus Creek-Thatcher Brook and Grannis Brook - peaked around 2:00 to 3:00 a.m. EDT on August 10 (Emergency responders, oral commun., 2009). Therefore, tributary inflows were decreasing as Cattaraugus Creek reached its highest stage 5 hours later, and peak flows in Cattaraugus Creek at Gowanda reflected contributions from headwater areas of the basin rather than from nearby tributaries.

Cattaraugus Creek itself was not a source of major flooding in Gowanda compared to the tributaries Thatcher Brook and Grannis Brook, which caused extensive flooding to the south and north of Cattaraugus Creek, respectively. Although flooding along Cattaraugus Creek occurred elsewhere (for example, see report cover photograph), the flows in the creek within the village limits of Gowanda were mostly contained by high banks. The only noted exceptions occurred upstream from the bridge on U.S. Highway 62 (Main Street) at the American Legion (on Legion Drive) on the north bank and at a residence directly across the creek (South Water Street) on the south bank. Both properties likely experienced some flooding from Grannis Brook and Thatcher Brook, respectively, but this flooding would have preceded flooding from Cattaraugus Creek by several hours. Flooding of these two properties occurred because they are at lower elevations than other properties along this reach.

\section{Collection of High-Water-Mark Data}

Two hundred forty-three high-water elevations in the flooded communities were surveyed by the USGS by differential leveling methods according to guidelines described by Kennedy (1988). A variety of surveying instruments, including an automatic optical level, a digital level, and a total station, were used to measure elevations to an accuracy of at least $0.01 \mathrm{ft}$. High-water marks are an indication of the water level at the peak stage of a river during a flood event and can be used to delineate a flooded area, compute peak streamflows, or calibrate peak-flow models used in flood-insurance studies. High-water marks are usually determined from mud, seed, or debris lines (or a combination thereof) left behind as the floodwaters receded or from wash lines where fine-grained soils have been eroded or loose vegetative material has been removed. High-water marks generally can be found on trees because seeds and small debris can get caught in the bark, but mud lines are common marks found in developed areas. The accuracy of the high-water marks is subjectively rated by the USGS personnel locating the mark, as outlined in Lumia and others (1986). High-water marks can be rated "excellent" (within $0.02 \mathrm{ft}$ of the "true" high-water mark), "good" (within $0.05 \mathrm{ft}$ ), "fair" (within $0.10 \mathrm{ft}$ ), or "poor" (greater than $0.10 \mathrm{ft}$ ). Typical high-water marks included debris lines (fig. 5A), wash lines on a sloping shale bank (fig. 5B), mud lines (fig. $5 \mathrm{C}$ and $\mathrm{D}$ ), and seed lines or grass on trees (fig. 5E). 


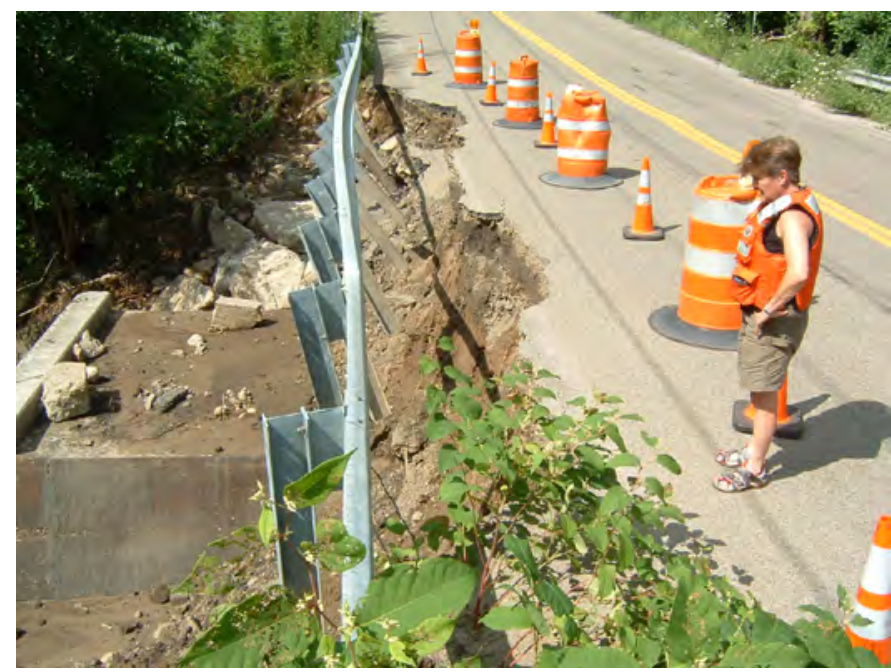

The fill above and the edge of the road on the downstream side of a concrete culvert were eroded.

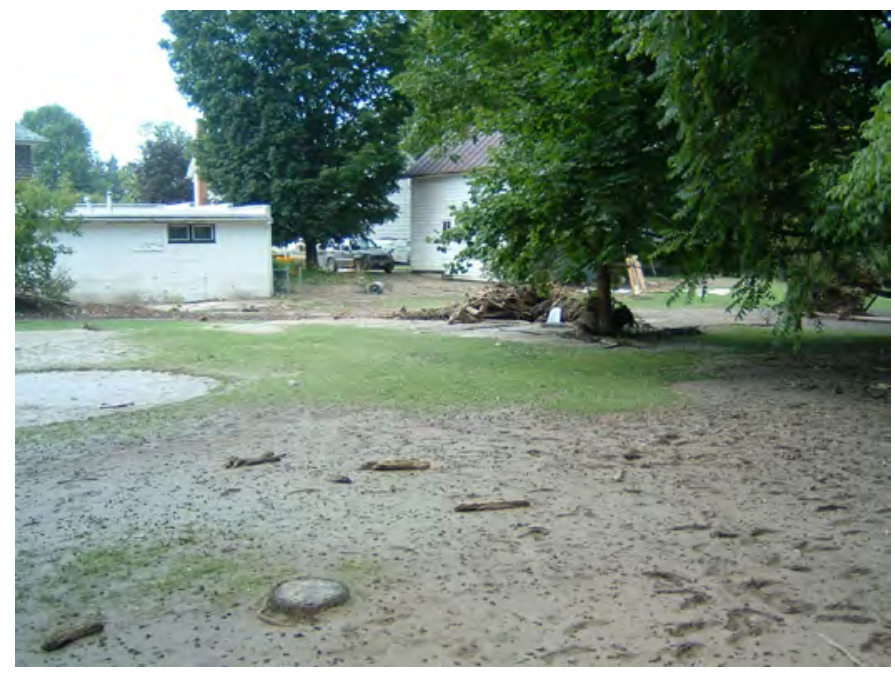

Mud and debris covered residential lawns.

Figure 3. Photographs of damage from the floods of August 10, 2009.

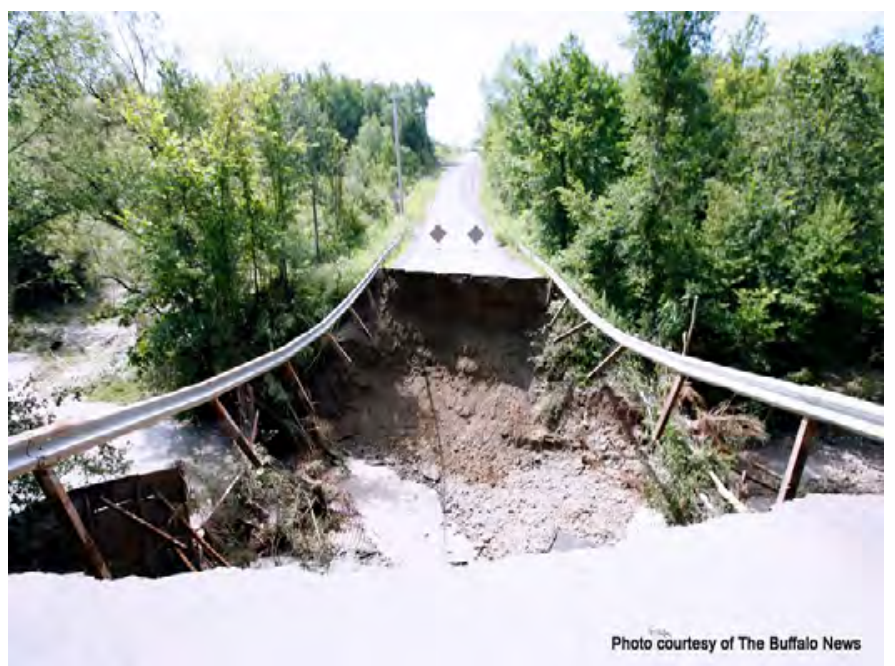

A culvert and road were completely washed away.

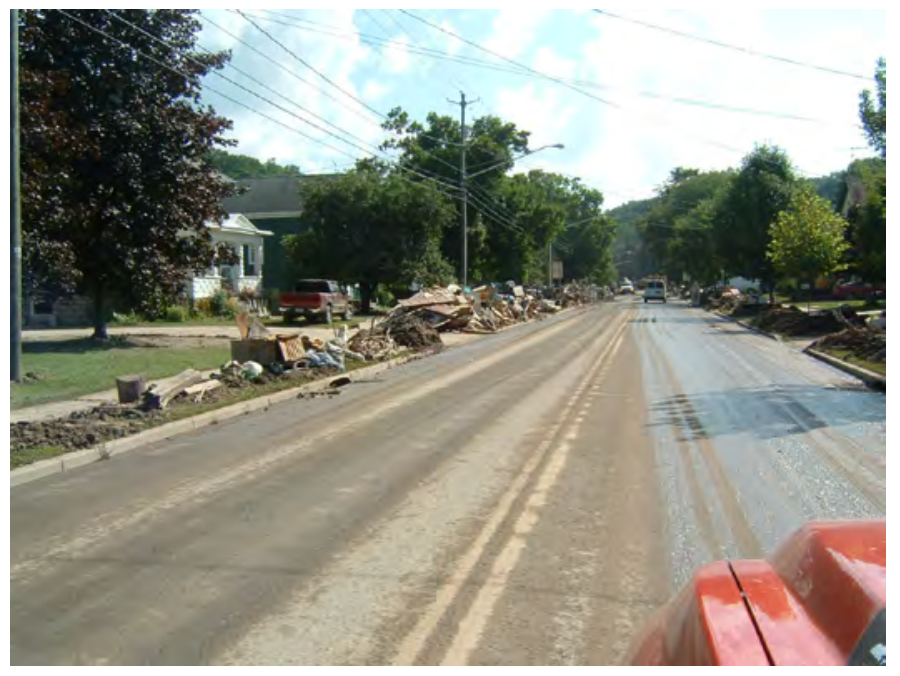

Mud-covered belongings from flooded basements were discarded and lined the streets of Gowanda.
During the field activities related to the flooding, which were conducted on August 12-13, August 18-21, September 8-9, and October 19-21, 2009, 155 and 88 high-water marks were located and surveyed within the village limits of Gowanda and Silver Creek, respectively. Many of these marks were used exclusively for estimation of peak flows in the streams that flowed through these communities. A subset of the marks (app. 1) was compiled to create water-surface profiles of the floods along the streams and maps of inundation in each of the flooded communities.

\section{Floodwater-Surface Profiles}

High-water marks that were surveyed along Grannis Brook (fig. 6) and Thatcher Brook (fig. 7) in Gowanda, and Walnut Creek (fig. 8) and Silver Creek (fig. 9) in the Village of Silver Creek, were used to create profiles of the water-surface elevations of the flood as it passed through the two communities. The high-water mark locations were picked from a plan drawing of the inundated areas and referenced to street intersections or other landmarks. The profiles were 


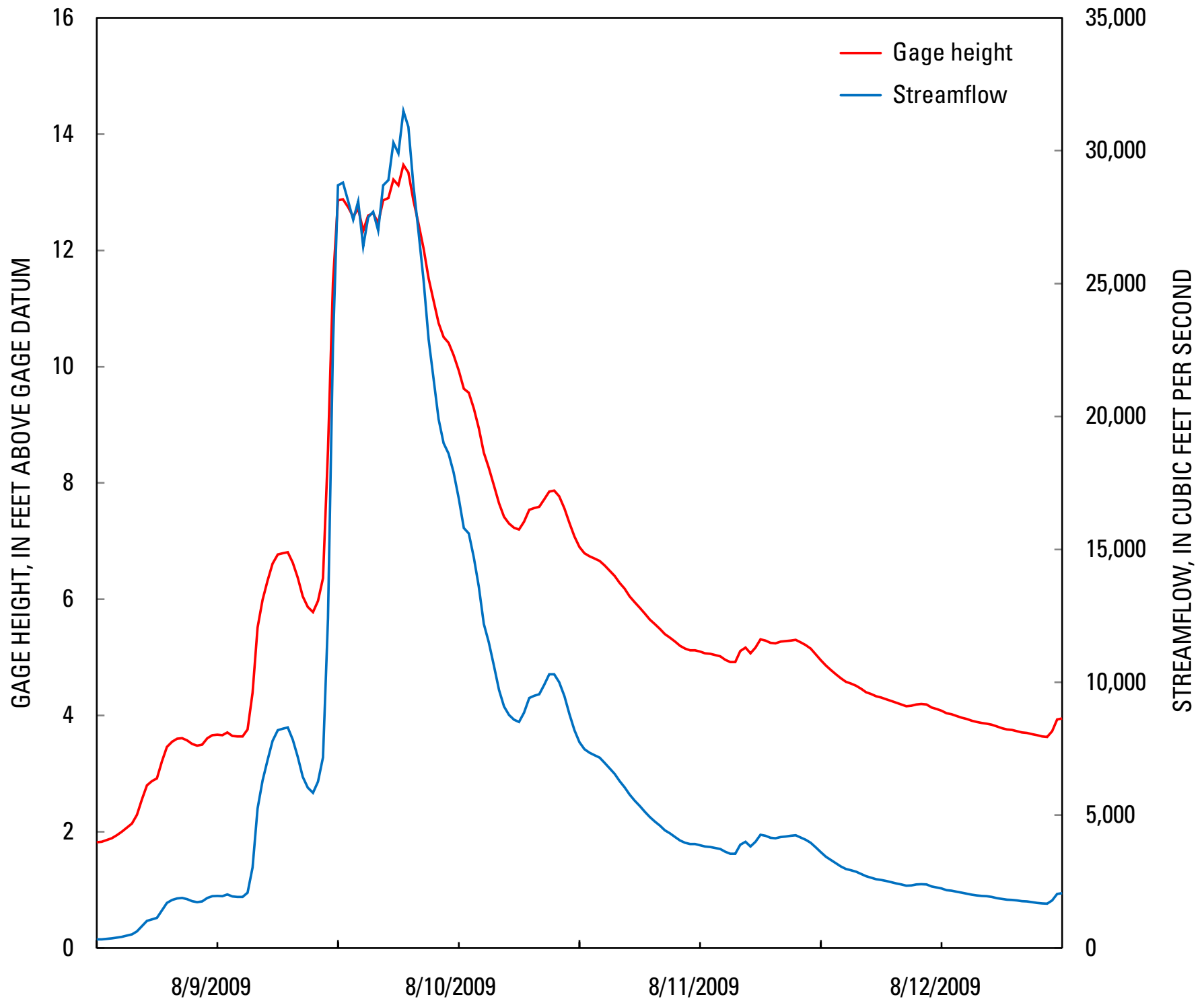

Figure 4. Streamflow and gage-height for Cattaraugus Creek at Gowanda, New York, U.S. Geological Survey station 04213500, August 9-12, 2009.

compared with those from the FEMA 0.2-percent annual exceedance probability (500-year recurrence interval) profiles (Federal Emergency Management Agency, 1983; 2009c). The profiles for Grannis Brook and Thatcher Brook were plotted to the North American Vertical Datum of 1988 (NAVD 88), whereas those for Walnut Creek and Silver Creek were plotted to the National Geodetic Vertical Datum of 1929 (NGVD 29), which are the respective datums used in the most recent FEMA flood-insurance reports. The plots showed that flood levels on August 10 along Grannis Brook were close to, or slightly higher than, the FEMA flood levels, whereas those along Thatcher Brook were 2 to $4 \mathrm{ft}$ higher at some points. The flood levels along Walnut and Silver Creeks were noticeably higher than the FEMA flood levels, at some locations as much as 6 to $8 \mathrm{ft}$ higher.

\section{Areal Extent of Flooding}

Floodwater-surface elevations, notes from USGS field personnel, and observations from community leaders and 

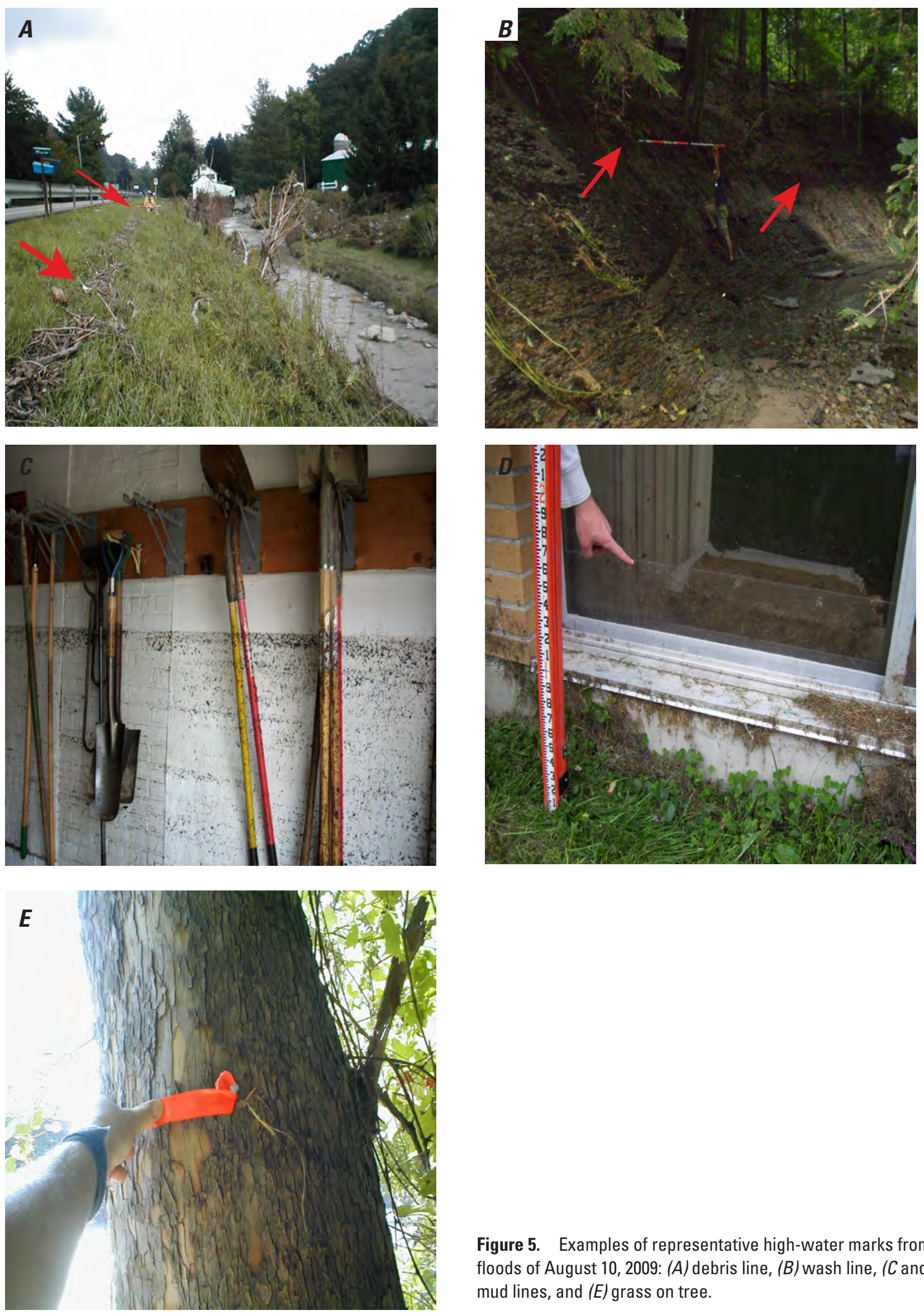

Figure 5. Examples of representative high-water marks from the floods of August 10, 2009: $(A)$ debris line, $(B)$ wash line, $(C$ and $D)$ mud lines, and (E) grass on tree. 


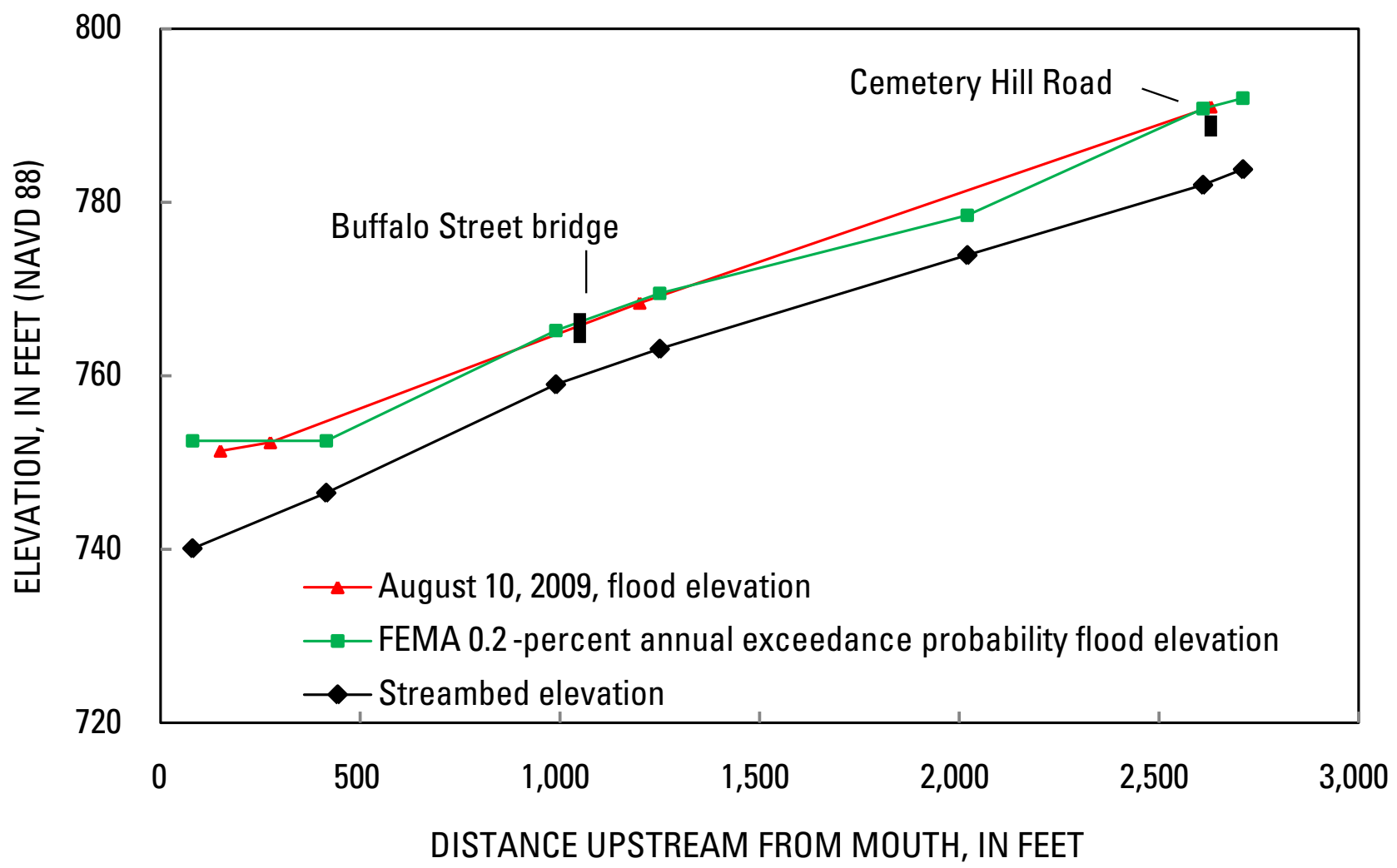

Figure 6. Water-surface elevations for the August 10, 2009, flood and the FEMA 0.2-percent annual exceedance probability flood for Grannis Brook at Gowanda, N.Y.

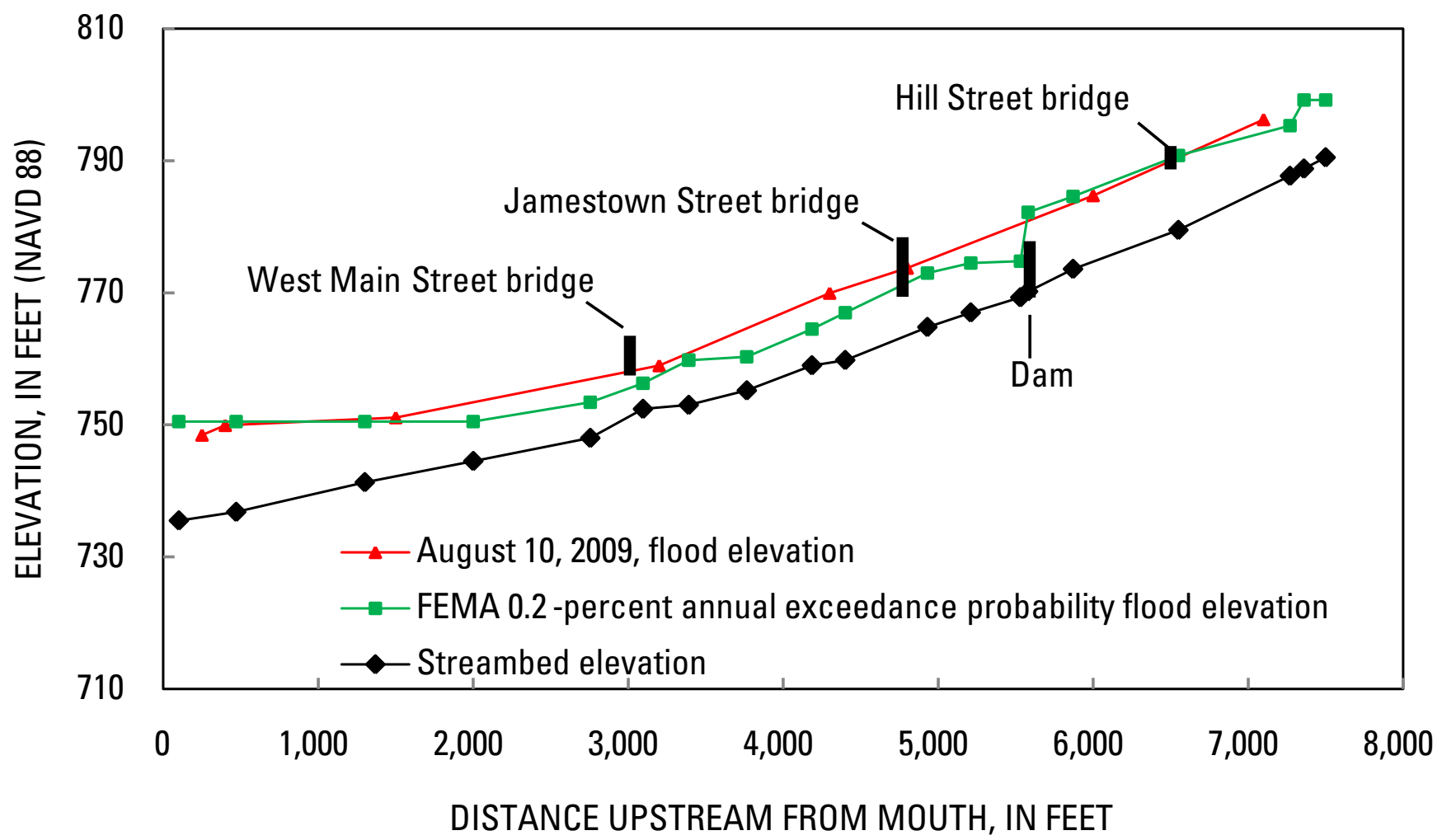

Figure 7. Water-surface elevations for the August 10, 2009, flood and the FEMA 0.2-percent annual exceedance probability flood for Thatcher Brook at Gowanda, N.Y. 


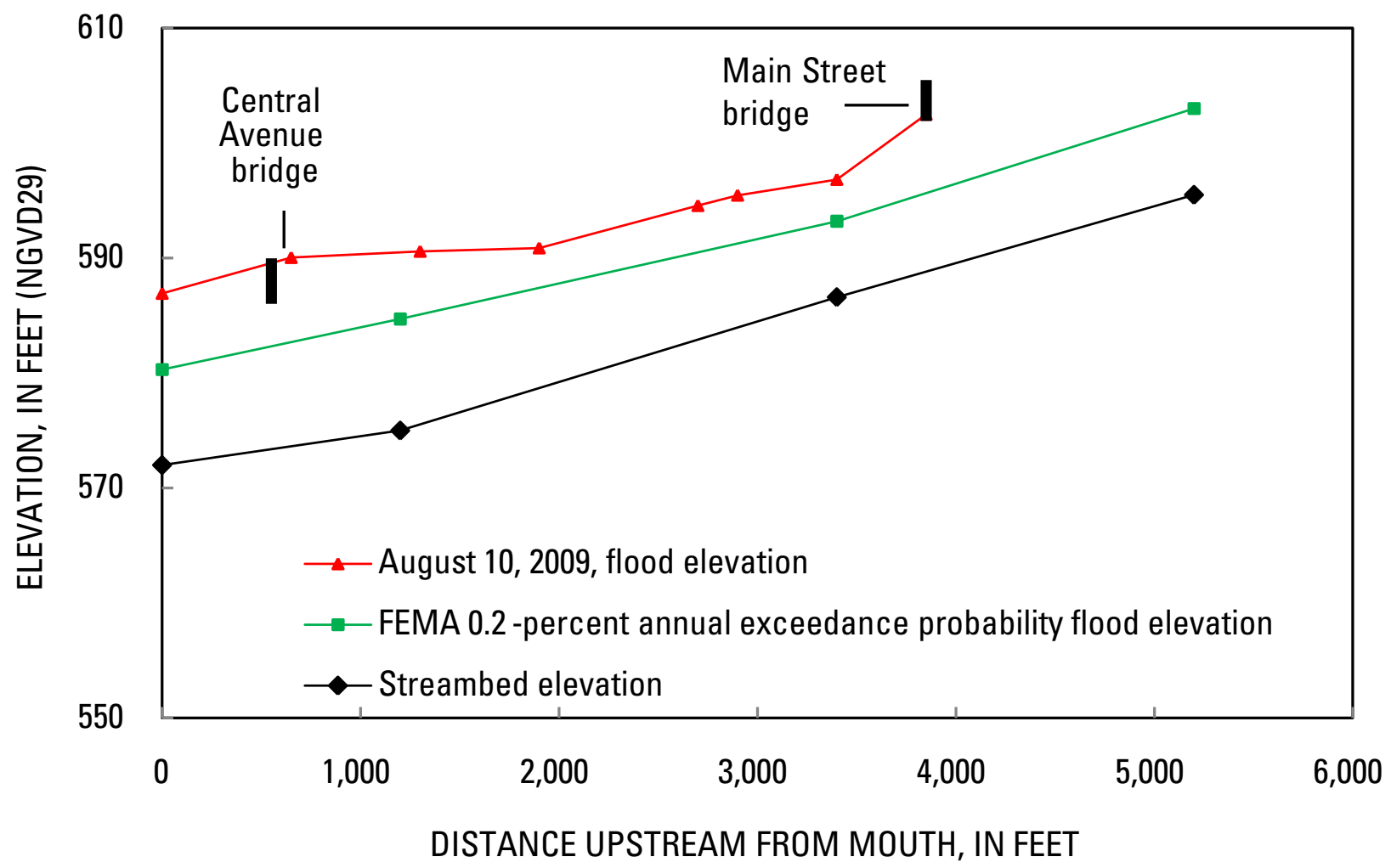

Figure 8. Water-surface elevations for the August 10, 2009, flood and the FEMA 0.2-percent annual exceedance probability flood for Walnut Creek at Silver Creek, N.Y.

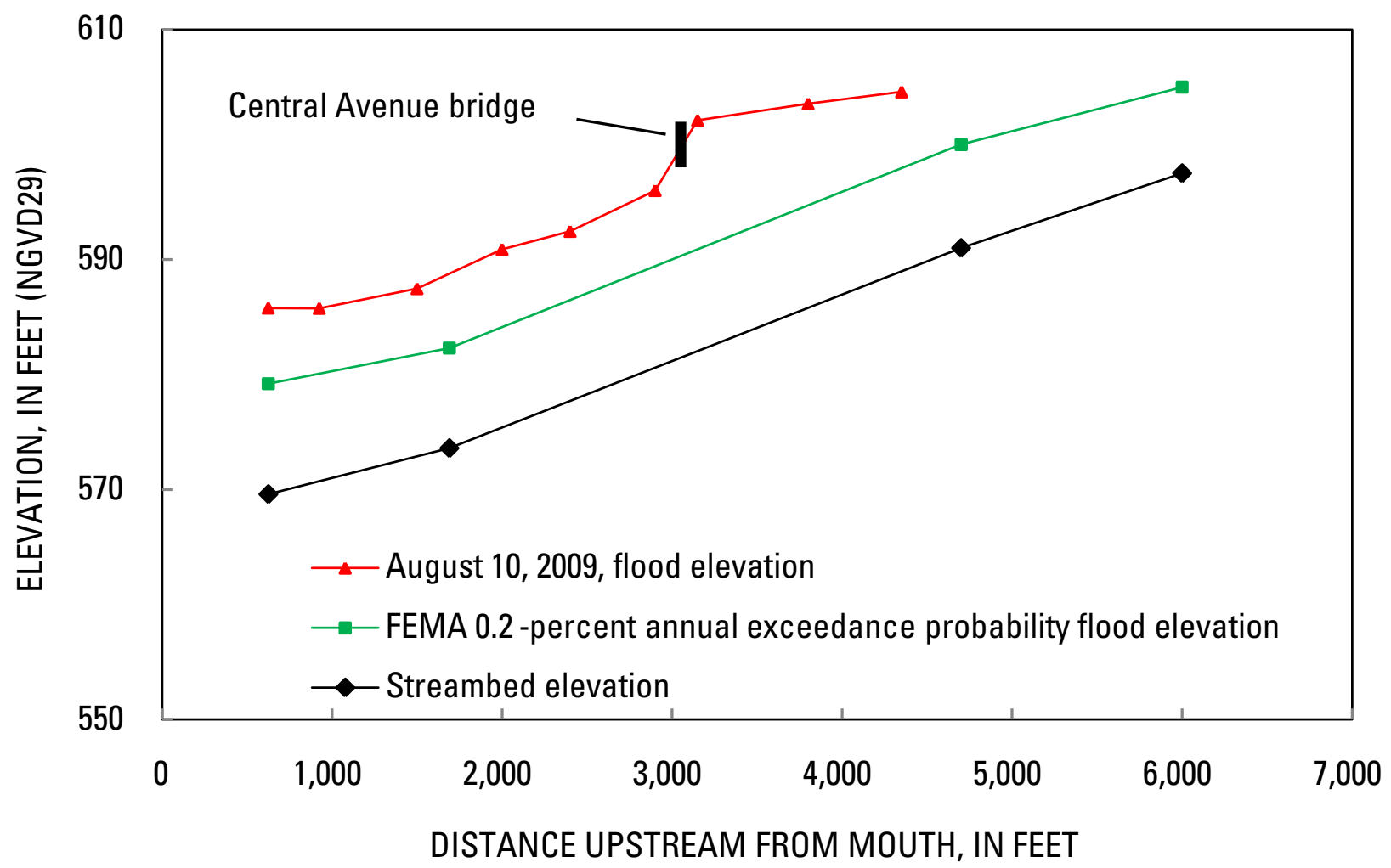

Figure 9. Water-surface elevations for the August 10, 2009, flood and the FEMA 0.2-percent annual exceedance probability flood for Silver Creek at Silver Creek, N.Y. 
emergency responders were used, along with a geographic information system, to create maps that showed the areal extent of flooding in Gowanda (fig. 10) and Silver Creek (fig. 11). Calculation of depth of inundation within these delineated areas was not possible because the 30-meter digital elevation data that were available were imprecise, and high-accuracy land-surface elevation data (such as LiDAR) were unavailable. As was done with the presentation of the water-surface-profile plots, the high-water elevations that are presented in these figures are referenced to different datums. Those for the Gowanda area are referenced to NAVD 88, whereas those for the Silver Creek area are referenced to NGVD 29. Again, this was done so that the August 10, 2009, data would be directly comparable to the data presented in the most recent FEMA flood-insurance report for each community.

Grannis Brook flooding was exacerbated by the culvert at Cemetery Hill Road, which because of its small size could not convey the flood flows and was partly blocked by debris. Water outside of the channel at this point flowed down East Main Street and Perry Street, through the adjacent residential areas (fig. 10). Floodwaters, up to $3 \mathrm{ft}$ deep, continued through the commercial area along Buffalo Street (U.S. Highway 62) before flowing into Cattaraugus Creek. At the south end of the village, floodwaters in Thatcher Brook had exceeded that channel's capacity to such a degree that water levels just south of the village limit overtopped the western bank on which U.S. Highway 62 is located (fig. 10). Water flowed down U.S. Highway 62 (Jamestown Street) through a railroad underpass, then through a residential area that, for lesser magnitude floods, would have been protected from flooding by the railroad embankment between this neighborhood and the brook. Downstream from the end of the railroad embankment (upstream from Hill Street), the floodwaters on either side of the embankment combined and flowed as sheet flow, in some cases more than $3 \mathrm{ft}$ deep, throughout the village from this point to Cattaraugus Creek.

Floodwaters in Silver Creek upstream from the village limit covered the vegetated floodplains on the insides of meander bends but were confined by the valley walls and caused no destruction of property. Once inside the village limits, however, floodwaters inundated the floodplain areas on which a trailer park and businesses had been built, caused extensive damage, and threatened the lives of residents and emergency responders. A similar situation occurred on Walnut Creek, but most of the damaged properties between Main Street (U.S. Highway 20) and Central Avenue (State Highway 5; fig. 11) were private residences. Water depths in these areas typically ranged from 3 to $5 \mathrm{ft}$ but increased to as much as $8 \mathrm{ft}$ in the area below the confluence of the two creeks, where the railroad embankment that parallels the Lake Erie shoreline caused the floodwater to pond before eventually draining through one of two outlets-Silver Creek or the Jackson Street railroad underpass (about $800 \mathrm{ft}$ to the west; fig. 11).

\section{Magnitudes of Peak Streamflows}

In addition to the flood sites on Grannis Brook, Thatcher Brook, and Silver Creek, peak streamflows presented in this report were determined at 12 USGS continuous-record or peak-flow-only streamgages in western New York (table 1). Stage-to-streamflow relations that had been previously defined by streamflow measurements at 11 of these sites were used to assign peak flows to the recorded peak gage heights. Indirect measurements of peak flows were made at four sites, including one continuous-record site where confirmation of the stageto-streamflow relation was desired and three ungaged sites on streams that were hardest hit by the August 10 floods but for which stage-to-streamflow relations had not been defined. Estimates of the peak flows in Grannis Brook, Thatcher Brook, and Cattaraugus Creek (all in Gowanda) were computed by the slope-area method following procedures described by Dalrymple and Benson (1967). Computations were performed by the USGS Slope-Area Computation program (Fulford, 1994). The estimated peak flows in Grannis Brook, Thatcher Brook, and Cattaraugus Creek were 1,400 ft $\mathrm{ft}^{3} / \mathrm{s}$, $7,600 \mathrm{ft}^{3} / \mathrm{s}$, and $33,200 \mathrm{ft}^{3} / \mathrm{s}$, respectively (table 2 ).

The computation of the peak flow in Silver Creek was complicated by erratic floodplain flow, a large contraction in flow area caused by a railroad bridge, and bypass flow though a railroad underpass. The peak flow in the main channel was computed using two methods: the openchannel width-contraction (or contracted opening) method (Matthai, 1967) and the critical-depth method (Barnes and Davidian, 1978) with the River Analysis System, HEC-RAS (Brunner, 2008). The results from the two computations agreed within 1 percent. The peak flow through the railroad underpass was computed using the flow-through-culvert method described by Bodhaine (1968) with the USGS Culvert Analysis Program (Fulford, 1998). The computed peak flows in the main and bypass channels of Silver Creek were $19,000 \mathrm{ft}^{3} / \mathrm{s}$ and $520 \mathrm{ft}^{3} / \mathrm{s}$, respectively (table 2 ).

\section{Annual Exceedance Probabilities of Peak Streamflows}

The annual exceedance probability is the chance that a flood of a given magnitude will be equaled or exceeded in any one year. The reciprocal of the annual exceedance probability is the recurrence interval, expressed in years. For example, a flood that has a 1 in 100 chance of being equaled or exceeded in any one year has an annual exceedance probability of 1 percent and a recurrence interval of 100 years (Holmes and Dinicola, 2010). This flood is commonly referred to as the 100 -year flood. Similarly, a 500 -year flood has a 0.2 -percent chance (or 1 in 500 chance) of being equaled or exceeded in a 


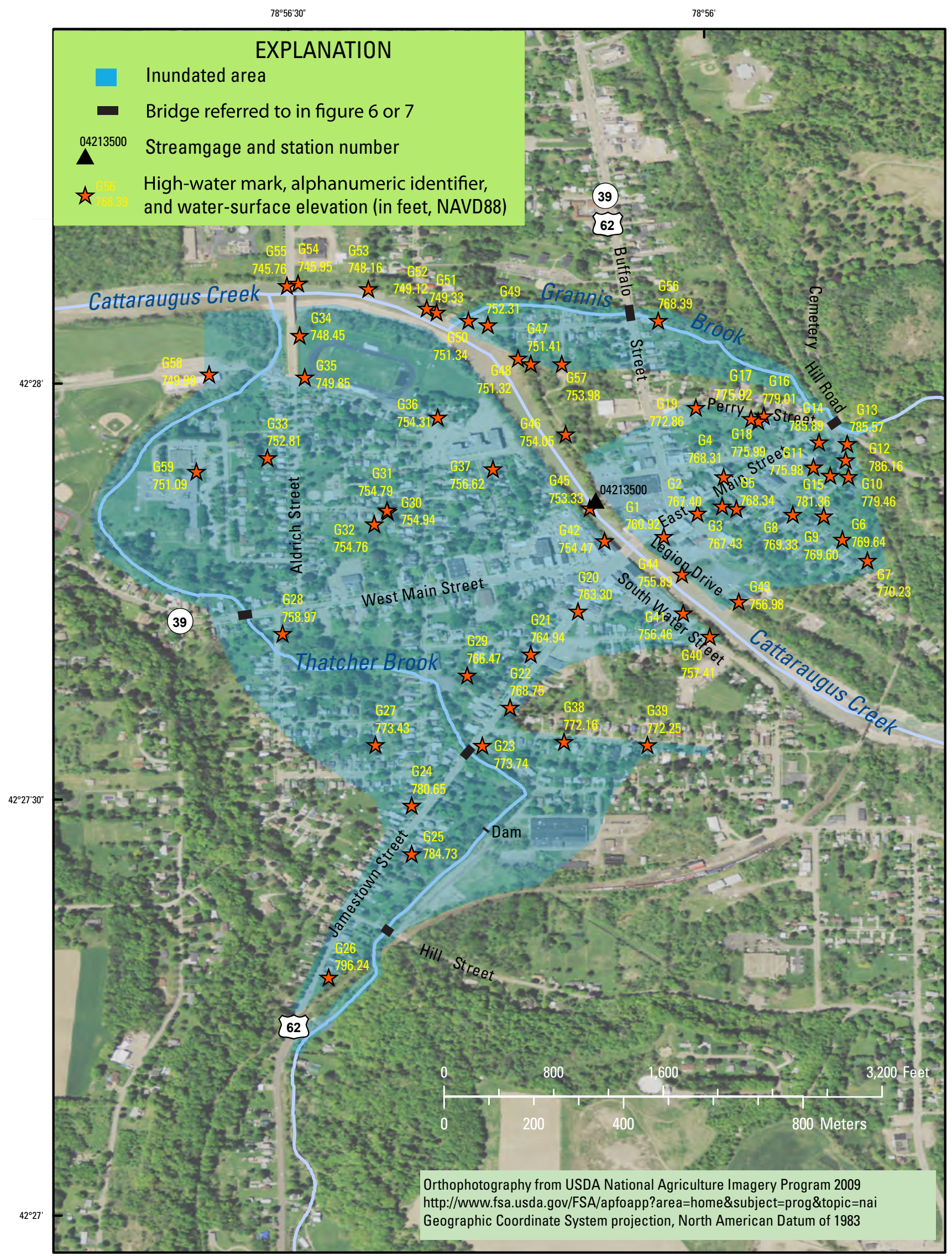

Figure 10. Areal extent and water-surface elevations of flooding in Gowanda, N.Y., August 10, 2009. 


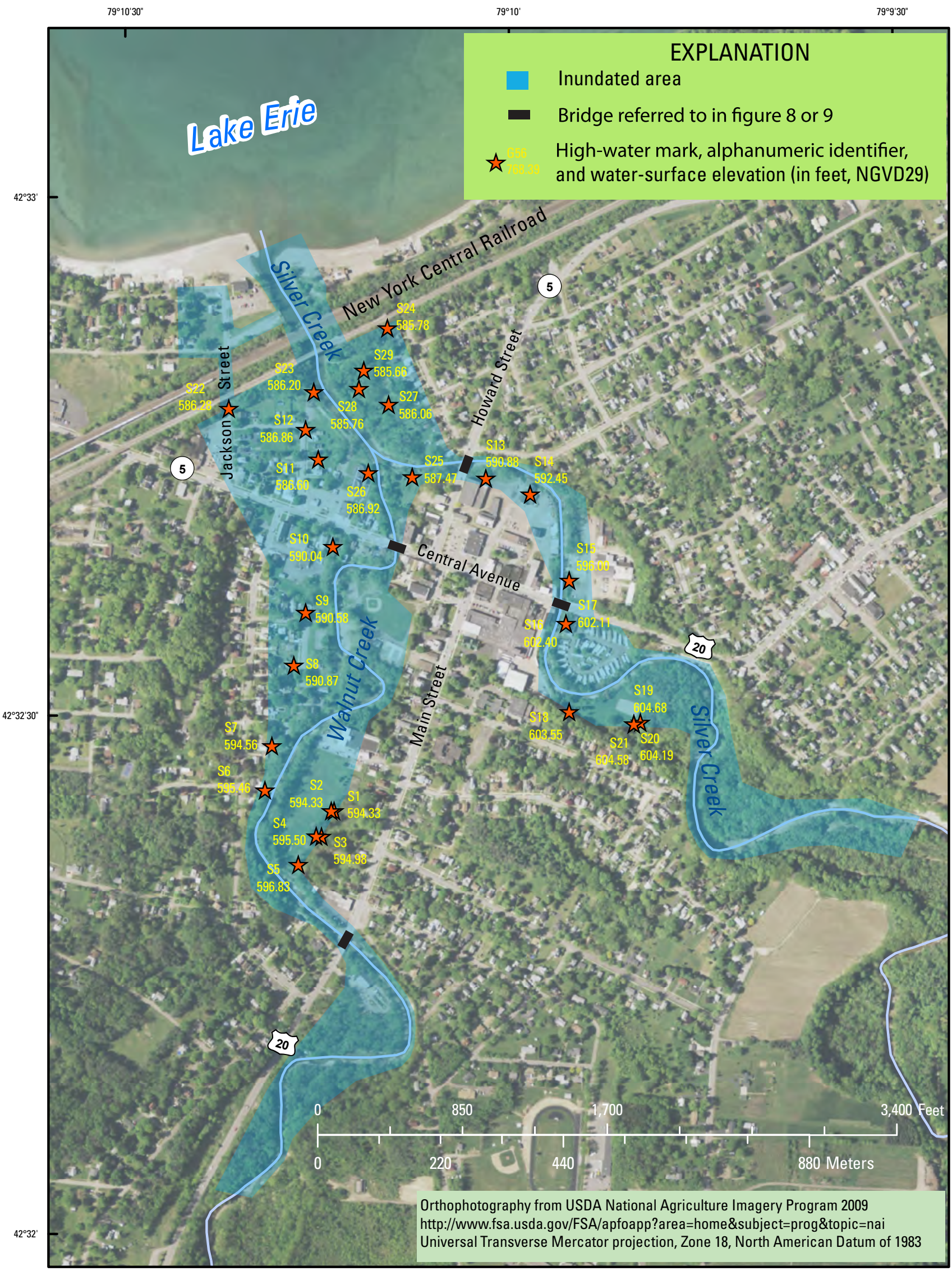

Figure 11. Areal extent and water-surface elevations of flooding in Silver Creek, N.Y., August 10, 2009. 


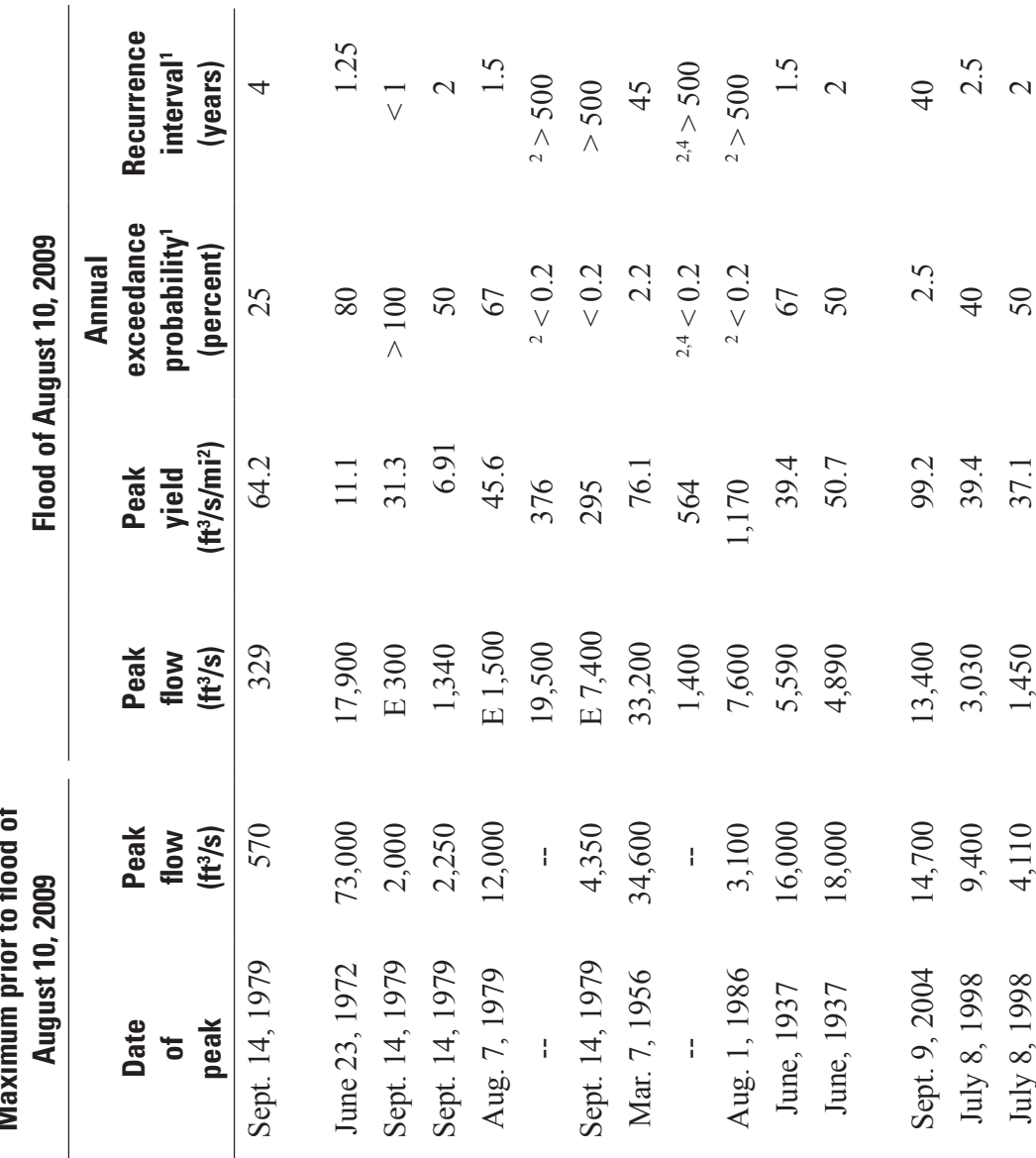

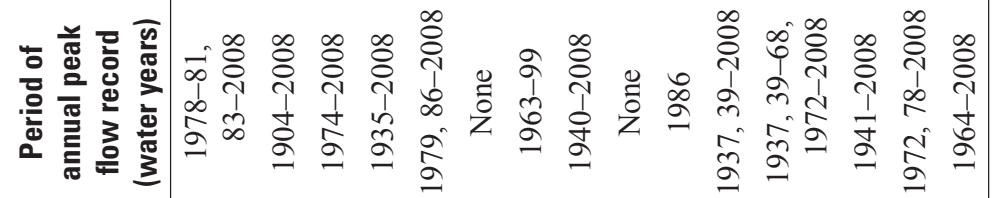

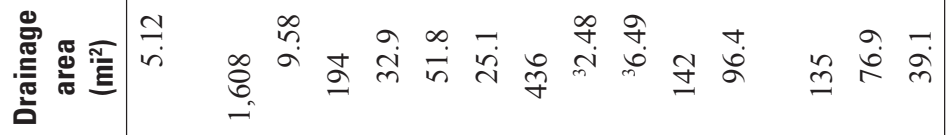

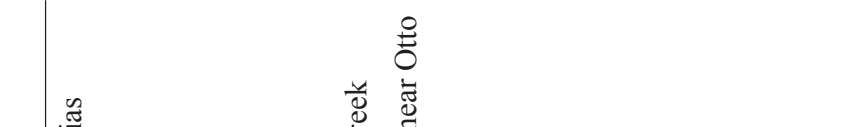


Table 2. Peak flows computed for the floods of August 10, 2009, at sites in Gowanda and Silver Creek, New York.

[Site locations are shown in figure $1 . \mathrm{mi}^{2}$, square miles; $\mathrm{ft}^{3} / \mathrm{s}$, cubic feet per second; --, no data]

\begin{tabular}{|c|c|c|c|c|c|c|}
\hline \multirow[b]{2}{*}{ Community } & \multirow[b]{2}{*}{ Stream } & \multirow[b]{2}{*}{$\begin{array}{l}\text { Drainage } \\
\operatorname{area}^{1}\left(\mathrm{mi}^{2}\right)\end{array}$} & \multicolumn{2}{|c|}{ Number of high-water marks } & \multirow[b]{2}{*}{$\begin{array}{c}\text { Type of indirect } \\
\text { measurement of flow }\end{array}$} & \multirow[b]{2}{*}{$\begin{array}{l}\text { Peak } \\
\text { flow } \\
\left(\mathrm{ft}^{3} / \mathrm{s}\right)\end{array}$} \\
\hline & & & Surveyed & $\begin{array}{l}\text { Included in final } \\
\text { maps and tables }\end{array}$ & & \\
\hline \multirow[t]{2}{*}{ Silver Creek } & Walnut Creek & 26.3 & 12 & 12 & (3) & -- \\
\hline & Silver Creek & 51.8 & 76 & 17 & Width contraction & ${ }^{4} 19,500$ \\
\hline \multirow[t]{2}{*}{ Gowanda } & Cattaraugus Creek & 436 & 49 & 16 & Slope area & 33,200 \\
\hline & Thatcher Brook & 6.49 & 59 & 22 & Slope area & 7,600 \\
\hline \multicolumn{7}{|c|}{${ }^{1}$ Drainage area at discharge measurement site. } \\
\hline \multicolumn{7}{|c|}{${ }^{2}$ See appendix 1 for list of high-water marks. } \\
\hline \multicolumn{7}{|c|}{$\begin{array}{l}{ }^{3} \text { The Silver Creek indirect measurement was made downstream from the confluence of Silver and Walnut Creeks and, therefore, is a measure of the combined } \\
\text { flows in both streams. }\end{array}$} \\
\hline
\end{tabular}

given year. The estimates of annual exceedance probabilities, which are statistically derived and based on peak flows measured or recorded on a particular stream, can be improved as the peak-flow record is extended. On streams where flow records are unavailable, regression equations (based on long-term peak-flow records from streams with similar basin characteristics) can be used to estimate flows with particular annual exceedance probabilities. Regression equations to estimate peak flows on rural, unregulated streams in six hydrologic regions in New York were developed by Lumia and others (2006) and are included in the program StreamStats (U.S. Geological Survey, 2010). The basin characteristics, which were deemed significant in estimating peak flows in the southwestern hydrologic region of New York that includes the study area, are drainage area, the main-channel slope, and mean annual precipitation.

Annual exceedance probabilities for peak flows at the indirect-measurement sites were compiled from available sources (table 3). Those for Grannis Brook, Thatcher Brook, and Cattaraugus Creek at Gowanda were obtained from the FEMA flood-insurance report for Erie County (Federal Emergency Management Agency, 2009c), and those for Silver Creek were obtained from the flood-insurance report for the Village of Silver Creek (Federal Emergency Management Agency, 1983). For comparison, peak flows for given annual exceedance probabilities were computed using StreamStats (U.S. Geological Survey, 2010) and also are presented in table 3.

The peak flow in Cattaraugus Creek at Gowanda had an annual exceedance probability of 2.2 percent ( 45 -year recurrence interval; table 1). The peak flows in Thatcher Brook and Silver Creek had annual exceedance probabilities less than 0.2 percent (recurrence intervals greater than 500 years). The annual exceedance probability of the peak flow in Grannis Brook was uncertain. On the basis of the FEMA flood-insurance report (Federal Emergency Management Agency, 2009c), the peak flow had an annual exceedance probability of 2.8 percent (35-year recurrence interval), which was incongruent when compared with the annual exceedance probabilities of the flows at other sites with small drainage areas that fell almost entirely within the area of heaviest precipitation. From StreamStats estimates (U.S. Geological Survey, 2010), the annual exceedance probability for the Grannis Brook peak was 0.2 percent (500-year recurrence interval; table 3), which agrees with the results for the other small-basin sites. Given the relative magnitude and flooding extent of the peak flow in Grannis Brook compared to those in Thatcher Brook and Silver Creek, an annual exceedance probability of 0.2 percent is reasonable and is presented in table 1 to quantify this peak flow.

Peak flows that occurred on August 10, 2009, and their annual exceedance probabilities were compiled for other USGS continuous-record and peak-flow-only streamgages in western New York (fig. 1; table 1). These data indicate that high flows occurred throughout western New York, but severe flooding was limited to the area that received the most intensive rainfall, as shown in figure 2. Only the site on South Branch Cattaraugus Creek near Otto (a discontinued peak-flow-only USGS streamgage) experienced a flood of a magnitude similar to the hard-hit areas of Gowanda and Silver Creek (less than 0.2 percent chance of exceedance). Cazenovia Creek at Ebenezer (near Buffalo) had a flow with a 2.5-percent 
Table 3. Peak flows for indicated annual exceedance probabilities for selected streams in Gowanda and Silver Creek, New York.

[Site locations are shown in figure $1 . \mathrm{mi}^{2}$, square miles; $\mathrm{ft}^{3} / \mathrm{s}$, cubic feet per second; --, no data]

\begin{tabular}{|c|c|c|c|c|c|c|}
\hline \multirow[b]{2}{*}{ Stream and location } & \multirow{2}{*}{$\begin{array}{l}\text { Drainage } \\
\text { area }\left(\mathrm{mi}^{2}\right)\end{array}$} & \multicolumn{5}{|c|}{ Peak flows $\left(\mathrm{ft}^{3} / \mathrm{s}\right)$ for indicated annual exceedance probabilities } \\
\hline & & 10-percent & 4-percent & 2-percent & 1-percent & 0.2-percent \\
\hline $\begin{array}{l}\text { Cattaraugus Creek } \\
\text { at Gowanda }\end{array}$ & 436 & 26,800 & -- & 36,800 & 41,500 & 52,000 \\
\hline \multirow{2}{*}{$\begin{array}{l}\text { Thatcher Brook at mouth } \\
\text { at Gowanda }{ }^{2}\end{array}$} & ${ }^{3} 7.38$ & 1,650 & -- & 2,400 & 2,700 & 3,100 \\
\hline & & \multicolumn{5}{|c|}{$\begin{array}{c}\text { Peak flows }\left(\mathrm{ft}^{3} / \mathrm{s}\right) \text { for indicated annual exceedance } \\
\text { probabilities computed using StreamStats }{ }^{4}\end{array}$} \\
\hline $\begin{array}{l}\text { Cattaraugus Creek at } \\
\text { Gowanda }^{5}\end{array}$ & & 24,400 & 29,900 & 34,200 & 38,700 & 50,000 \\
\hline $\begin{array}{l}\text { Grannis Brook at mouth at } \\
\text { Gowanda }\end{array}$ & & 518 & 690 & 840 & 992 & 1,390 \\
\hline $\begin{array}{l}\text { Thatcher Brook at mouth } \\
\text { at Gowanda }\end{array}$ & & 1,360 & 1,820 & 2,230 & 2,640 & 3,730 \\
\hline \multicolumn{7}{|c|}{${ }^{1}$ Federal Emergency Management Agency (1983). } \\
\hline
\end{tabular}

annual exceedance probability (40-year recurrence interval). Other sites distant from the intensive precipitation area had flows with annual exceedance probabilities equal to or greater than 25 percent (recurrence intervals equal to or less than 4 years).

\section{Summary}

A severe thunderstorm struck western New York, south of Buffalo, during the night of August 9, 2009, and caused flash flooding during the early morning of August 10 in parts of Cattaraugus, Chautauqua, and Erie Counties. Nearly 6 inches of rain fell in 1.5 hours as recorded by a National Weather Service observer in Perrysburg, which lies between Gowanda and Silver Creek, the communities that suffered the most damage. The rainfall intensity of this storm had less than a 0.2 -percent chance of occurring during a given year (that is, it exceeded the 500-year storm event) and reportedly caused water levels in Walnut Creek in the Village of Silver Creek to rise 3 to 4 feet in 30 minutes. Numerous road culverts were washed out, and more than one-quarter of the roads in Cattaraugus County were damaged. Many people were evacuated or rescued in both communities, including patients in the Tri-County Memorial Hospital in Gowanda and residents of a creek-side trailer park in Silver Creek, which was destroyed. The water supplies of both communities were compromised by damages to village reservoirs and water-transmission infrastructures. Water and mud damage to residential and commercial properties was extensive. Two deaths occurred during the flood in Gowanda. One resident suffered a heart attack while emergency responders were delayed by floodwaters. A second resident drowned when he 
fell into Thatcher Brook after the floodwaters had undercut the land on which he was standing. The tri-county area was declared a Federal disaster area, and more than $\$ 45$ million in Federal assistance was distributed to more than 1,500 individuals and an estimated 1,100 public projects. The total cost of damages estimated by emergency managers in the affected counties and municipalities exceeded $\$ 90$ million. Peak flows in small basins, such as Grannis Brook, Thatcher Brook, and Silver Creek, occurred between 2:00 and 3:00 a.m. EDT on August 10, 2009, and were the cause of the severe flooding and associated damages in the Villages of Gowanda and Silver Creek. The peak flow in Cattaraugus Creek at Gowanda, which was not a cause of major flooding in this community, occurred about 5 hours after the small tributaries had peaked.

Over 240 high-water marks were surveyed by the U.S. Geological Survey; a subset of these marks was used to create floodwater-surface profiles for four streams and to delineate the areal extent of flooding in Gowanda and Silver Creek. Flood elevations exceeded previously defined Federal Emergency Management Agency (FEMA) 0.2-percent annual exceedance probability (500-year recurrence interval) elevations by 2 to 4 feet in Gowanda and as much as 6 to $8 \mathrm{ft}$ in Silver Creek. Most of the high-water marks were used in indirect hydraulic computations to estimate peak flows for four streams. The peak flows in Grannis Brook and Thatcher Brook were computed, using the slope-area method, to be 1,400 and 7,600 cubic feet per second, respectively, and peak flow in Silver Creek was computed, using the widthcontraction method, to be 19,500 cubic feet per second. The annual exceedance probabilities for flows in these and other basins with small drainage areas that fell almost entirely within the area of heaviest precipitation were less than 0.2 percent (or recurrence intervals greater than 500 years). The peak flow in Cattaraugus Creek at Gowanda was computed, using the slope-area method, to be 33,200 cubic feet per second and had an annual exceedance probability of 2.2 percent (recurrence interval of 45 years).

\section{Acknowledgments}

The authors thank the many residents of the flooded communities for their descriptions of the flood and their cooperation in helping field crews locate high-water marks. Timothy Roche, Chief of Police, Silver Creek, provided valuable information regarding the flood in Silver Creek, as well as photographs of flood damage in the village. Ralph Crawford, Silver Creek Highway Superintendent, and Michael Hutchinson, Gowanda Superintendent of Public Works, provided feedback on the delineation of the inundated areas in their respective communities.

\section{References Cited}

Barnes, H.H., and Davidian, J., 1978, Indirect methods, in Herschy, R.W., ed., Hydrometry-principles and practices: New York, Wiley, p. 189-190.

Bodhaine, G.L., 1968, Measurement of peak discharge at culverts by indirect methods: U.S. Geological Survey Techniques of Water-Resources Investigations, book 3, chap. A3, 60 p.

Brunner, G.W., 2008, HEC-RAS, River analysis system user's manual, version 4.0: U.S. Army Corps of Engineers, Hydrologic Engineering Center, report CPD-68, 733 p.

Dalrymple, Tate, and Benson, M.A., 1967, Measurement of peak discharge by the slope-area method: U.S. Geological Survey Techniques of Water-Resources Investigations, book 3, chap. A2, 12 p.

Fairbanks, Phil, Michel, Lou, and Binkley, Collin, 2009, Creek goes on rampage: The Buffalo News Newspaper, August 11, 2009, p. 1-2.

Federal Emergency Management Agency, 1983, Flood insurance study, Village of Silver Creek, Chautauqua County, New York: Federal Emergency Management Agency, $18 \mathrm{p}$.

Federal Emergency Management Agency, 2009a, President declares major disaster for New York: Federal Emergency Management Agency, accessed July 29, 2010, at http:// www.fema.gov/news/newsrelease.fema?id $=49434$.

Federal Emergency Management Agency, 2009b, Combined disaster assistance to western New York will top \$45 million: Federal Emergency Management Agency, accessed July 29, 2010, at http://www.fema.gov/news/newsrelease. fema?id $=49960$.

Federal Emergency Management Agency, 2009c, Flood insurance study, Erie County, New York (all jurisdictions), Volume 1 of 5: Federal Emergency Management Agency, accessed February 10, 2010, at New York - Mapping Status, http://www.rampp-team.com/ny.htm.

Flynn, Lisa, 2009, Gowanda water supply dwindling: WIVB. com, accessed April 20, 2010, at http://www.wivb.com/dpp/ news/gowanda_water_supply_dwindling_090811.

Fulford, J.M., 1994, User's guide to SAC, a computer program for computing discharge by slope-area method: U.S. Geological Survey Open-File Report 94-360, 31 p. 
Fulford, J.M., 1998, User's guide to the U.S. Geological Survey culvert analysis program, version 97-08:

U.S. Geological Survey Water-resources Investigations Report 98-4166, 70 p.

Holmes, R.R., Jr., and Dinicola, Karen, 2010, 100-year flood-It's all about chance: U.S. Geological Survey General Information Product 106, 1 p., accessed April 19, 2010, at http://pubs.usgs.gov/gip/106/pdf/100-yearflood_041210web.pdf.

Kennedy, E.J., 1988, Levels at streamflow gaging stations: U.S. Geological Survey Open-File Report 88-710, 38 p.

Lumia, Richard, Burke, P.M., and Johnston, W.H., 1986, Flooding of December 29, 1984 through January 2, 1985, in northern New York State, with flood profiles of the Black and Salmon Rivers: U.S. Geological Survey WaterResources Investigations Report 86-4191, 53 p.

Lumia, Richard, Freehafer, D.A., and Smith, M.J., 2006, Magnitude and frequency of floods in New York: U.S. Geological Survey Scientific Investigations Report 2006-5112, $152 \mathrm{p}$.

Matthai, H.F., 1967, Measurement of peak discharge at width contractions by indirect methods: U.S. Geological Survey Techniques of Water-Resources Investigations, book 3, chap. A4, 44 p.

National Oceanic and Atmospheric Administration, 2010a, Storm data and unusual weather phenomena, August 2009, Volume 51, Number 8: National Oceanic and Atmospheric Administration, National Climatic Data Center, Asheville, N.C., accessed September 7, 2010, at http://www.ncdc.noaa. gov/oa/mpp.
National Oceanic and Atmospheric Administration, 2010b, Satellite and Information Service, Climate Data Center, accessed April 19, 2010, at http://www7.ncdc.noaa.gov/ $\mathrm{CDO} / \mathrm{cdo}$.

National Weather Service, 2009, Flash flood event in southern Erie, northern Chautauqua and northern Cattaraugus Counties, accessed October 15, 2009, at http://www.wbuf. noaa.gov/svrwx/web_090810_Flashflood/indexflood.html.

Thompson, Carolyn, 2009, Two die in Gowanda: ObserverToday.com, accessed August 14, 2009, at http://www.observertoday.com/page/content.detail/ $\mathrm{id} / 527609 . h t m l$.

Wagner, L.A., and Dixson, H.L., 1985, Drainage areas of New York streams, by river basins-a stream gazetteer, data through 1984: U.S. Geological Survey Open-File Report 81-1055, 359 p.

U.S. Geological Survey, 2010, New York StreamStats: U.S. Geological Survey, accessed May 28, 2010, at http:// streamstatsags.cr.usgs.gov/ny_ss/default.aspx?stabbr=ny\&d $\mathrm{t}=12737674080151$. 
Appendix 1. High-water marks in the Villages of Gowanda and Silver Creek, N.Y., for the flash floods of August 10, 2009 


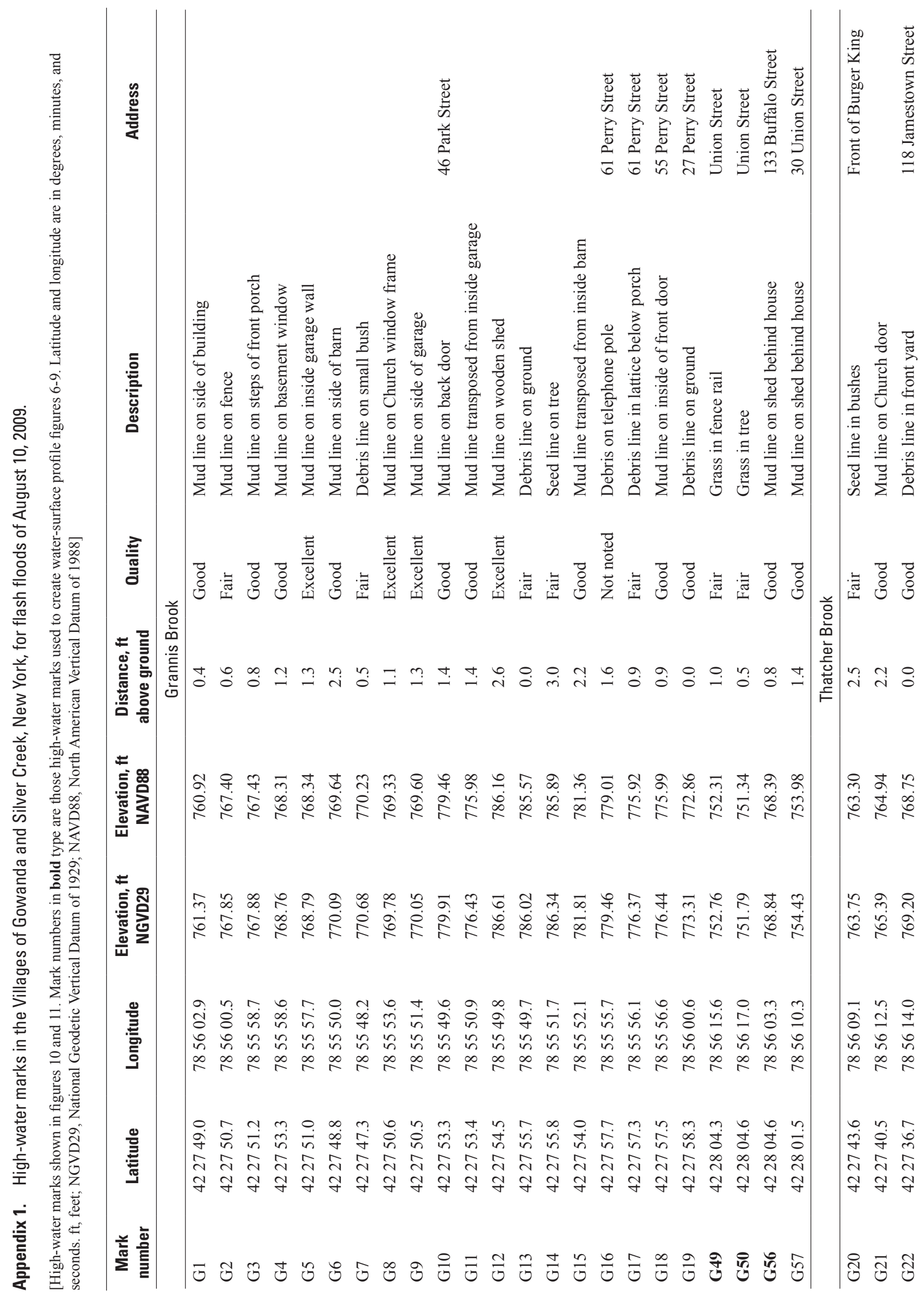




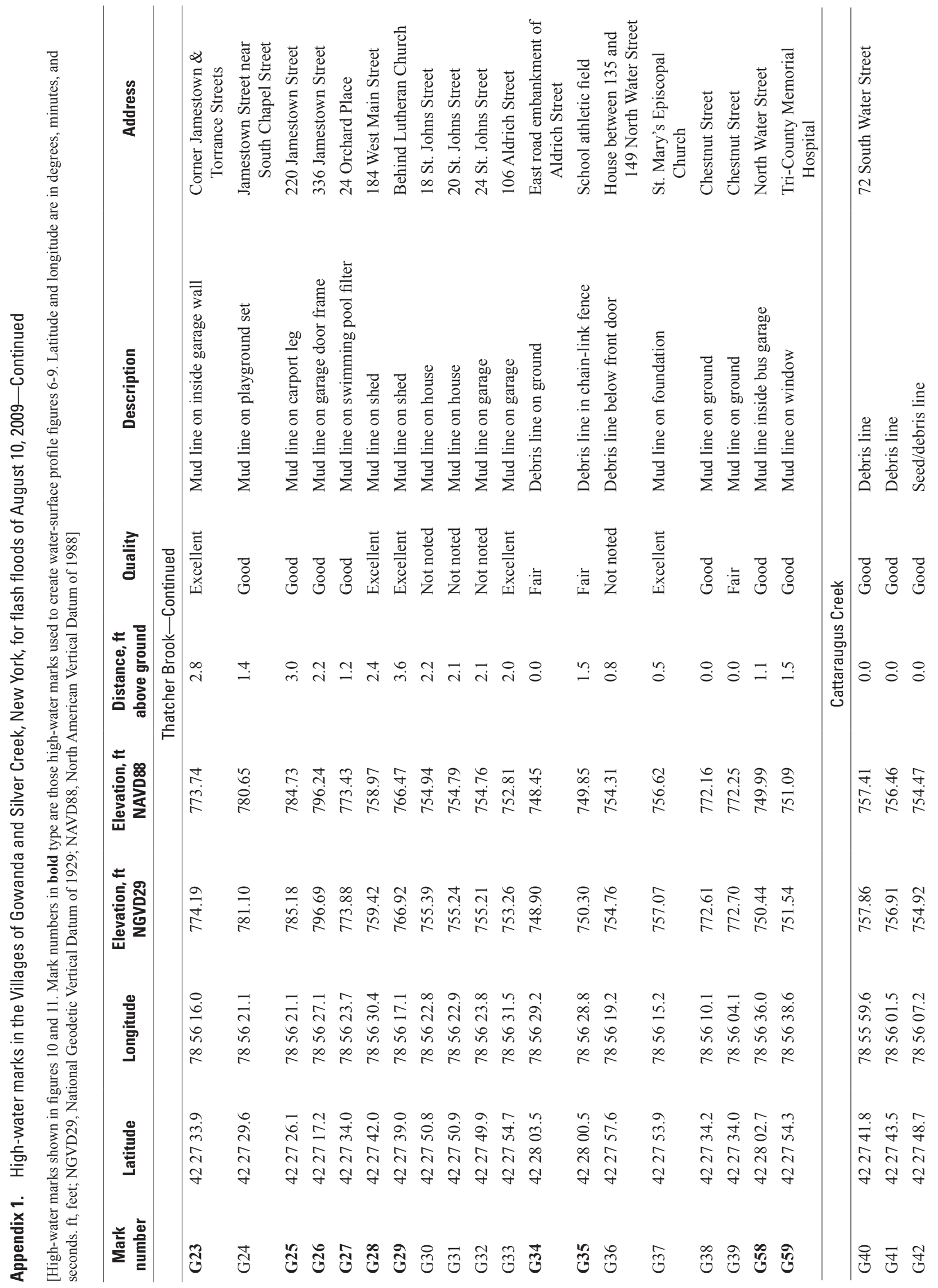




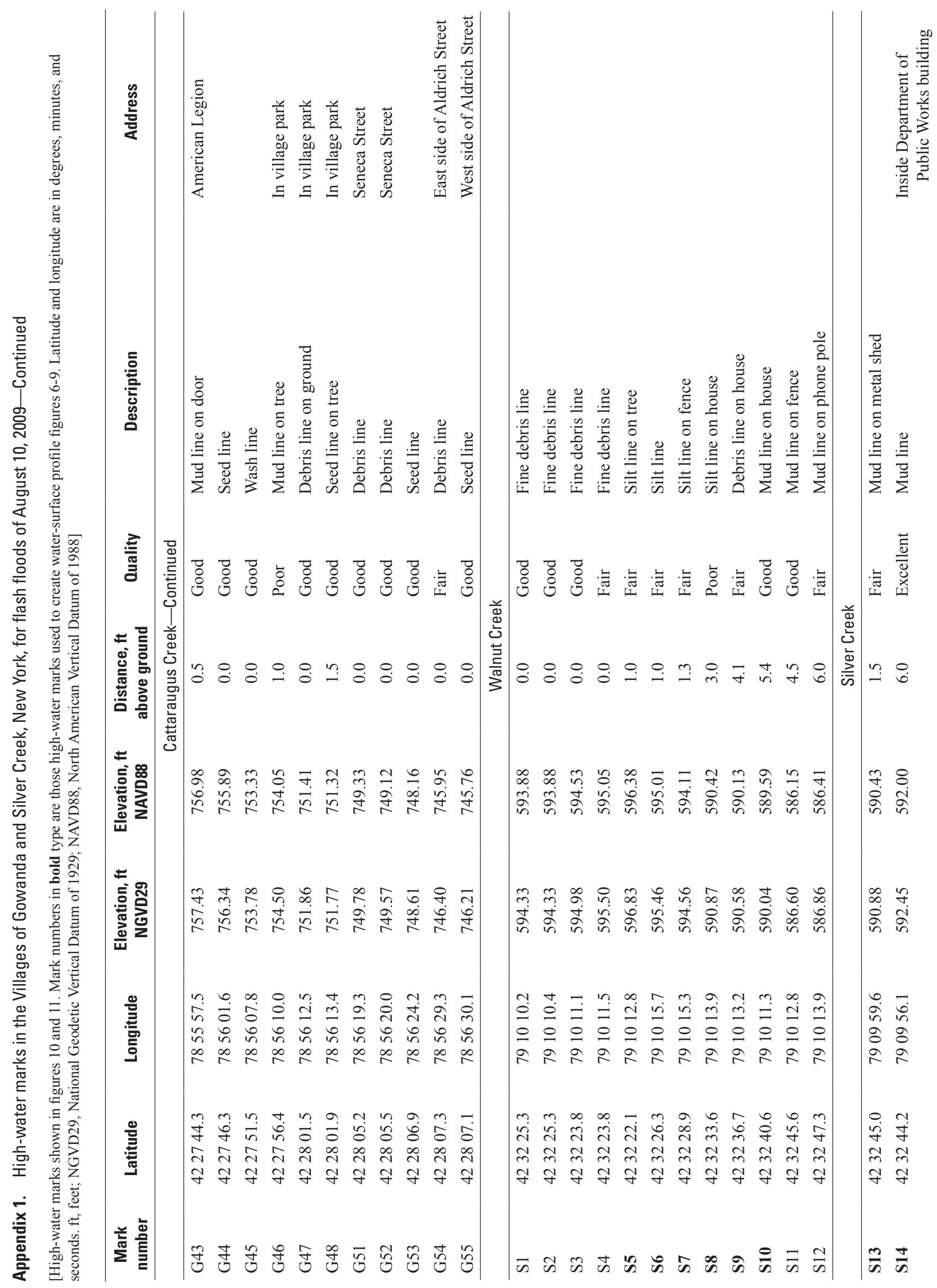




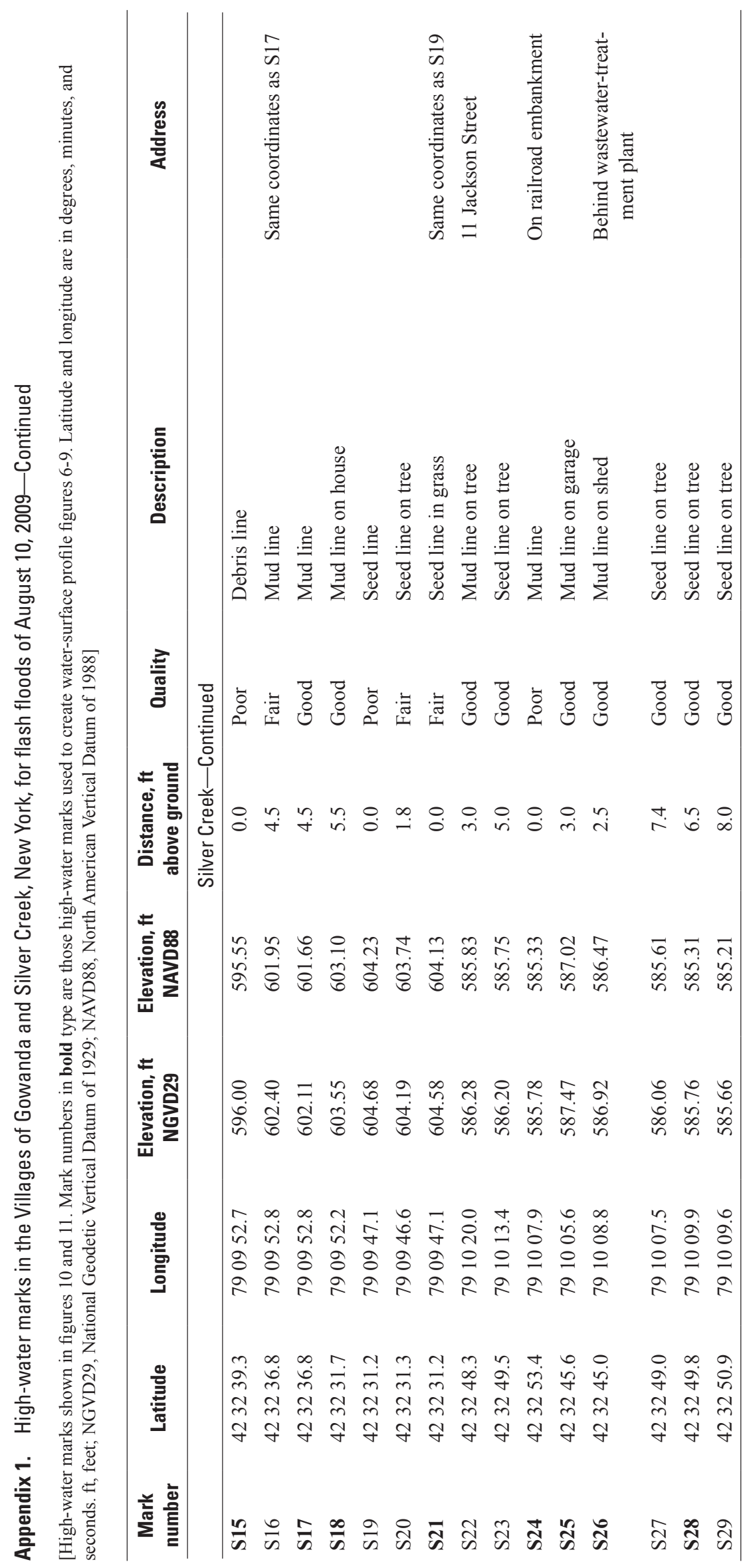


Prepared by the Pembroke, Lafayette and West Trenton Publishing Service Centers.

For more information concerning this report, contact:

Director

U.S. Geological Survey

New York Water Science Center

425 Jordon Rd

Troy, NY 12180

dc_ny@usgs.gov

or visit our Web site at:

http://ny.water.usgs.gov 
